\title{
Cell type influences the molecular mechanisms involved in hormonal regulation of ERG $\mathrm{K}^{+}$channels
}

\author{
Luis Carretero • Francisco Barros • Pablo Miranda • \\ Jorge Fernández-Trillo • Angeles Machín • \\ Pilar de la Peña • Pedro Domínguez
}

Received: 23 February 2012 /Accepted: 25 February 2012 /Published online: 14 March 2012

(C) Springer-Verlag 2012

\begin{abstract}
While the thyrotropin-releasing hormone (TRH) effect of raising intracellular $\mathrm{Ca}^{2+}$ levels has been shown to rely on $\mathrm{G}_{\mathrm{q} / 11}$ and PLC activation, the molecular mechanisms involved in the regulation of ERG $\mathrm{K}^{+}$channels by TRH are still partially unknown. We have analysed the effects of $\beta \gamma$ scavengers, Akt/PKB inactivation, and TRH receptor (TRH$\mathrm{R})$ overexpression on such regulation in native and heterologous expression cell systems. In native rat pituitary $\mathrm{GH}_{3}$ cells $\beta$-ARK/CT, $G \alpha_{t}$, and phosducin significantly reduced TRH inhibition of rERG currents, whereas in HEK-H36/T1 cells permanently expressing TRH-R and hERG, neither of the $\beta \gamma$ scavengers affected the TRH-induced shift in $V_{1 / 2}$. Use of specific siRNAs to knock Akt/PKB expression down abolished the TRH effect on HEK-H36/T1 cell hERG, but not on rERG from $\mathrm{GH}_{3}$ cells. Indeed, wortmannin or long insulin pretreatment also blocked TRH regulation of ERG currents in HEK-H36/T1 but not in $\mathrm{GH}_{3}$ cells. To determine whether these differences could be related to the amount of TRH-Rs in the cell, we studied the TRH concentration dependence of the $\mathrm{Ca}^{2+}$ and ERG responses in $\mathrm{GH}_{3}$ cells overexpressing the receptors. The data indicated that independent of the receptor number additional cellular factor(s) contribute differently to couple the TRH-R to hERG channel modulation in HEK-H36/T1 cells. We conclude that regulation of ERG currents by TRH and its receptor is transduced in $\mathrm{GH}_{3}$ and HEK-H36/T1 cell systems through
\end{abstract}

Electronic supplementary material The online version of this article (doi:10.1007/s00424-012-1094-y) contains supplementary material, which is available to authorized users.

L. Carretero $\cdot$ F. Barros $\cdot$ P. Miranda $\cdot$ J. Fernández-Trillo $\cdot$

A. Machín $\cdot$ P. de la Peña $\cdot$ P. Domínguez $(\triangle)$

Departamento de Bioquímica y Biología Molecular, Edificio

Santiago Gascón, Campus del Cristo, Universidad de Oviedo,

33006, Oviedo, Spain

e-mail: pdluengo@uniovi.es common and different elements, and hence that the cell type influences the signalling pathways involved in the TRHevoked responses.

Keywords ERG potassium channels · Signal transduction . Cell type dependence · G-protein · Protein kinase B ·

Thyrotropin-releasing hormone

\section{Introduction}

The human ERG (hERG) $\mathrm{K}^{+}$channel has been recognized as an important determinant of action potential characteristics in heart muscle and its inhibition by inherited mutations or many cardiac-related and non-cardiac-related prescribed drugs has been associated with an increased risk of cardiac arrhythmia and sudden death [16, 30]. Furthermore, ERG channels also seem to play a key role setting the electrical behaviour of other cell types including neurones and pituitary, glial, chromaffin, pancreatic $\beta$, and tumour cells $[1,55]$. Interestingly, the observation that arrhythmogenic syncopes are usually associated with physical, emotional or auditory stress, suggests a link between hormonal (e.g. adrenergic) stimulation and cardiac ion channel function including hERG [53]. For that reason, many research groups have focussed on hormonal control of the channel, and the regulatory pathways used by such agents have been studied using both native and heterologous systems. While some pathways involved in control of hERG by different hormones have been elucidated, the molecular mechanisms of hERG regulation by different physiological agents remain unclear.

In native lactotrophs and clonal GH adenohypophysial cells, endogenous ERG currents are inhibited by activation of the G-protein and phospholipase C (PLC)-coupled 
thyrotropin-releasing hormone receptor (TRH-R) $[3,4,8,9$, 47, 48]. The TRH-R is coupled to a G-protein of the $\mathrm{G}_{\mathrm{q} / 11}$ family for activation of phosphatidylinositol 4,5-bisphosphate hydrolysis leading to a "classical" $\mathrm{Ca}^{2+}$ and diacylglycerol/protein kinase $\mathrm{C}$ cascade (reviewed in [22]). However, TRH-induced inhibition of ERG currents in pituitary cells does not depend on protein kinase $\mathrm{C}$ or protein kinase A activation $[3,4,8,9,47,48]$ and a pathway for ERG regulation by TRH involving $\mathrm{G}_{\mathrm{s}}$ and/or $\mathrm{G}_{13}$ has been recognized by our group in $\mathrm{GH}_{3}$ cells [40]. Our initial results also showed a significant attenuation of the TRHinduced inhibition in cells overexpressing the $\alpha$ subunit of transducin $\left(G \alpha_{t} ;[40]\right)$, an agent known to sequester free $\beta \gamma$ complexes released from G-proteins [43].

Heterologous expression in Xenopus oocytes and mammalian cells, such as CHO and HEK293 cells, is extensively used to better understand the electrophysiological properties of ion channels, but also the signalling pathways involved in its hormonal modulation. Specifically, HEK293 cells permanently expressing hERG channels and hormone receptors have been used as a simple and defined model system to better define these parameters in the case of hERG [40, 58, $60]$, and it has been reported that basal activity of Akt/ protein kinase $\mathrm{B}[13,21,24]$ is required for normal function of hERG channels stably expressed in these cells [58]. However, the possible participation of this kinase in hormonal regulation of ERG channels either in this heterologous expression system or in native $\mathrm{GH}_{3}$ cells remains unknown. Interestingly, preliminary experiments in a HEK293 cell line (HEK-H36/T1) permanently expressing hERG channels and TRH-Rs suggested that some differences could exist between the G-protein coupling and the transduction cascades involved in the TRH-induced modulation of the native ERG currents in $\mathrm{GH}_{3}$ cells and hERG in the heterologous expression system [40].

In this work, we have checked the possibility that the cell type could be affecting which elements are involved in the modulation of ERG currents. We have used scavengers of G-protein $\beta \gamma$ dimers and found that they impair the ability of TRH to modulate ERG currents in $\mathrm{GH}_{3}$ but not in HEKH36/T1 cells. We also blocked the activity of Akt/PKB kinase using siRNAs or pharmacological agents and found that whereas it is indeed necessary for the TRH-induced modulation of hERG in HEK-H36/T1 cells, it is not a requisite for the modulation of endogenous ERG currents in native $\mathrm{GH}_{3}$ cells. Finally, we present results indicating that, although only a single population of TRH binding sites is present in both cell types, channel regulation shows different dependence on hormone concentration in $\mathrm{GH}_{3}$ and HEK-H36/T1 cells not related to the level of receptor expression in the cells. All these data strongly support that the TRH pathway can lead to distinct downstream signalling patterns as a function of the cell type.

\section{Materials and methods}

Plasmids and chemicals

The original plasmid containing the cDNA for the HERG channel was a generous gift of Dr. E. Wanke (University of Milano, Italy). $G \alpha_{t}$ cDNA (provided by Dr. J.S. Gutkind, NIDCR, NIH, Bethesda) was cloned as an EcoRI/XhoI fragment in pcDNA3 (Invitrogen). Bovine phosducin cDNA was cloned as a Hind III fragment in pcDNA3.1/Hygro (Invitrogen). The carboxy-terminal segment of the $\beta$ adrenergic receptor kinase ( $\beta$-ARK/CT or $\beta$-ARK1 (438689) carboxyl-terminal minigene [34]) cloned en pREP4 (Invitrogen) was a gift of Dr. F. Mayor (CBM, CSIC, Madrid). TRH-R/YFP was prepared in our lab by cloning TRH-R cDNA [19] as a Hind III-Bam HI fragment in pEYFP-N1 (Clontech). Plasmid pEGFP-C1 (Clontech) was also used as a transfection reporter. Fura-2 and Fura-2/AM were from Molecular Probes, and TRH, insulin, nystatin, and RIPA buffer were from Sigma-Aldrich. E-4031 was from Alomone Labs. Specific siRNAs were ordered from Thermo-Fisher, and negative control siRNAs were ONTARGETplus Non-targeting pool from Dharmacon. AntiAkt antibodies were from Cell Signaling or from Santa Cruz, anti- $\beta$-actin was from Sigma, and anti-GAPDH from Santa Cruz. Anti-mouse and anti-rabbit secondary antibodies were either HRP-linked from Cell Signaling or fluorophore-linked from LI-COR Biosciences.

\section{Cell culture and transfection}

$\mathrm{GH}_{3}$ rat anterior pituitary cells (ATCC-CCL 82.1) were grown in poly-L-lysine coated coverslips as previously detailed [23, 40, 41]. Generation and culture conditions of HEK-H36/T1 cells have been detailed elsewhere [40, 41]. Cells trypsinized $24 \mathrm{~h}$ prior to transfection were transiently transfected using Lipofectamine 2000 (Invitrogen) according to the manufacturer's instructions. Unless otherwise indicated, $5.0 \mu \mathrm{g}$ of plasmids containing the different constructs and $0.5 \mu \mathrm{g}$ of pEGFP-C1 coding for green fluorescent protein (EGFP) as a marker for transfection (ratio 10:1) were used. The mixture of $5.5 \mu \mathrm{g}$ of total DNA and Lipofectamine 2000 was incubated in serum-free medium for $20 \mathrm{~min}$ and added to the plates containing the cells in serum-containing medium without antibiotics. Recordings were performed $48-72 \mathrm{~h}$ after transfection. Sometimes cells were plated in standard dishes without poly-L-lysine and used to measure Akt expression.

Electrophysiological recordings, solutions and data analysis

Current recordings were performed at room temperature with the perforated-patch variant of the patch-clamp technique using nystatin and as detailed elsewhere $[2,3,5,6,23$, 
40, 41]. Electrode resistance amounted to 2-5 $\mathrm{M} \Omega$ when filled with the pipette solution containing (in $\mathrm{mM}$ ): $65 \mathrm{KCl}$, $30 \mathrm{~K}_{2} \mathrm{SO}_{4}, 10 \mathrm{NaCl}, 1 \mathrm{MgCl}_{2}, 50$ sucrose, and 10 HEPES (pH 7.4 with $\mathrm{KOH}$ ). rERG current data are shown without correction for leakage and capacitive transients. A P/n method was used for leak and capacitive current subtraction of the hERG recordings in HEK-H36/T1 cells.

The standard extracellular saline used for perforation and monitoring $\left[\mathrm{Ca}^{2+}\right]_{i}$ (see below) contained (in $\mathrm{mM}$ ): $137 \mathrm{NaCl}$, $4 \mathrm{KCl}, 1.8 \mathrm{CaCl}_{2}, 1 \mathrm{MgCl}_{2}, 10$ glucose, and $10 \mathrm{HEPES}$ (pH 7.4 with $\mathrm{NaOH}$ ). Recordings of rERG currents in $\mathrm{GH}_{3}$ cells were performed after changing the extracellular medium to high- $\mathrm{K}^{+}, \mathrm{Ca}^{2+}$-free solution once permeabilization of the patches had been completed [2, 3, 5, 6, 23, 40]. This solution contained (in mM): $140 \mathrm{KCl}, 4 \mathrm{MgCl}_{2}, 10 \mathrm{EGTA}$, and 10 HEPES titrated to $\mathrm{pH} 7.4$ with $\mathrm{KOH}$. In this case, inward currents were studied during hyperpolarization pulses to $-100 \mathrm{mV}$ from a holding potential of $-10 \mathrm{mV}$. The magnitude of the inward currents was estimated as the total inward charge computed between cursors located at 0.5 and $100 \%$ duration of the hyperpolarization pulses [40]. hERG currents were recorded in HEK-H36/T1 cells in standard extracellular saline following the pulse protocols indicated in the figures. Kinetic parameters of activation and deactivation were obtained as previously described [7, 40, 41]. The voltage dependence of current activation was assessed using standard tail current analysis. Tail current magnitudes normalized to maximum were fitted with a Boltzmann function:

$h(V)=I_{\max }\left[1 /\left(1+\exp \left(\left(V-V_{1 / 2}\right) / k\right)\right)\right]$

where $V$ is the test potential, $V_{1 / 2}$ is the half-activation voltage, and $k$ is the slope factor. The rates of deactivation in the HEKH36/T1 cells were determined from negative-amplitude biexponential fits to the decaying phase of tail currents. Monoexponential fits to the decaying currents at $-100 \mathrm{mV}$ after subtracting the currents remaining in the presence of E-4031 were used in the case of the $\mathrm{GH}_{3}$ cells. In all cases, the first cursor of the fitting window was advanced to the end of the initial hook due to the recovery of inactivation [40, 41].

Intracellular calcium measurements

Measurements of intracellular $\mathrm{Ca}^{2+}$ concentrations $\left(\left[\mathrm{Ca}^{2+}\right]_{i}\right)$ were performed in cells plated on poly-L-lysine-coated coverslips as indicated above. Procedures for cell loading with the $\mathrm{Ca}^{2+}$-sensitive dye Fura- 2 and $\left[\mathrm{Ca}^{2+}\right]_{i}$ recordings have been detailed elsewhere [40]. $\mathrm{Ca}^{2+}$ concentrations were estimated from the ratio of the Fura- 2 emission intensities for 340/380 nm excitations, after comparison with Fura-2 standards [5, 40]. In this case, YFP instead of GFP was used as a marker of transfection to prevent interference with the Fura-2 fluorescence.

\section{RNA interference}

Expression of Akt/PKB genes in HEK-H36/T1 or $\mathrm{GH}_{3}$ cells was blocked by using siRNA mixtures prepared against human Akt1 (NM_001014432.1) or rat Akt1 (NM_0033230.1) sequences, prepared as follows. Total RNA from HEK-H36/ T1 or $\mathrm{GH}_{3}$ cells was retrotranscribed using a human $\left(5^{\prime}\right.$ AGCTGCAGAAGTCCTTAACATTTG) or rat (5'GAGAAACAAAACCATCAGGTACAG) Akt1 primer. Then, human or rat Aktl cDNAs were amplified by PCR using specific primers with a T7 promoter sequence (5'-CGCTAATACGACTCACTATAGGG) attached to their 5' end. Human Akt1 cDNA was amplified from positions 1335 to 2105 (forward: 5'-T7-CCACCATGAAGACCTTTTGC; reverse: 5'-T7ACACCCGGAGAACAAACTGG) and rat Akt1 cDNA was amplified from positions 359 to 1427 (forward: 5'-T7TGGCTGATGGACTCAAACGG; reverse: 5'-T7-TCCACA CACTCCATGCTGTC). After amplification, PCR products were purified, quantified, and sequenced. Next, human or rat Akt1 cDNA fragments were in vitro transcribed from the T7 promoter with MEGAscript ${ }^{\circledR}$ T7 High Yield Transcription Kit (Ambion), and the dsRNAs were purified and quantified. Finally, dsRNAs were treated with BLOCK-iT" ${ }^{\mathrm{TM}}$ Dicer Enzyme (Invitrogen), and siRNAs mixtures purified from uncut dsRNA fragments using BLOCK-iT ${ }^{\mathrm{TM}}$ RNAi Purification Kits (Invitrogen), quantified, and checked for the correct size. In some experiments, specific siRNAs were used targeting rat Akt1 (1112: 5'-UGUUCGAGCUCAUCCUAAUTT) or human Akt1 (501: 5'-ACUUCCUCCUCAAGAAUGATT), which had been designed using available siRNA prediction programs and checked by a BLAST search to have no relevant sequence homology to other genes. HEK-H36/T1 and $\mathrm{GH}_{3}$ cells were transfected with $0.5-1.0 \mu \mathrm{g}$ of the corresponding siRNAs mix or $100 \mathrm{pmol}$ of the specific siRNA, plus $1 \mu \mathrm{g}$ of pEGFP-C1 plasmid, using $3 \mu \mathrm{l}$ of Lipofectamine 2000 in $300 \mu \mathrm{l}$ of serum-free medium. This mixture was incubated for $20 \mathrm{~min}$ and added to the $35 \mathrm{~mm}$ dishes containing the cells in serum-containing medium without antibiotics. Control cells were transfected with $1 \mu \mathrm{g}$ of ON-TARGETplus Non-targeting pool (Dharmacon) containing a mix of four siRNAs nontargeting for human and rat genes. The amount of transfection reagent was selected to keep the cell membranes suitable for electrophysiological measurements.

\section{Western blot analysis}

The expression levels of Akt/PKB proteins were measured $48 \mathrm{~h}$ after transfection with the siRNAs. Due to their very low transfection efficiency, expression of Akt/PKB proteins in $\mathrm{GH}_{3}$ cells was only measured in fluorescent cells (i.e. transfected with pEGFP-C1) after sorting them with a FACStar Plus Cell Sorter (Becton Dickinson), in order to better estimate the siRNAs effects. Cells were washed and 
collected in PBS, resuspended in $100 \mu \mathrm{l}$ of RIPA buffer and disrupted by sonication three times for 2 min followed by 1 min incubations on ice. After centrifugation of lysates at $16,000 \times g$ for $15 \mathrm{~min}$ at $4{ }^{\circ} \mathrm{C}$, the supernatants were recovered, and the concentration of protein was determined using the BCA ${ }^{\text {TM }}$ Protein Assay Kit (Pierce). Samples were mixed with SDS-PAGE loading buffer, heated at $95^{\circ} \mathrm{C}$ for $5 \mathrm{~min}$, and resolved in $8 \%$ or $10 \%$ SDS-PAGE gels. Then, proteins were transferred to PVDF Hybond-P membranes (Amersham-GE Healthcare) and blocked according to the antibodies manufacturer's instructions. Signal was detected using either SuperSignal West Pico Chemiluminescent Substrate (Pierce) with Kodak X-Omat LS films, or the Odyssey (LI-COR Biosciences) infrared detection system.

\section{Statistics}

Data values given in the text and in figures with error bars represent mean \pm S.E.M. for the number of indicated cells. Comparison between data groups was at first performed by parametric Student's unpaired $t$ test (2-tailed) or ANOVA. Due to dispersion of the data in individual cells after some treatments, non-homogeneous variances (as evidenced after a Bartlett's test) were sometimes obtained. Therefore, alternate Welch $t$ test assuming Gaussian populations with unequal SD's was used. In all cases, $p$ values $<0.05$ were considered as indicative of statistical significance. When indicated, $n$ represents the number of tested cells and $N$ the number of transfections.

\section{Results}

Effect of G-protein $\beta \gamma$ scavengers on TRH-induced modulation of ERG channels

Previous work from our laboratory indicated that introduction in $\mathrm{GH}_{3}$ adenohypophysial cells of $\mathrm{G} \alpha$, able to act as a scavenger of $\beta \gamma$ dimers released from G-proteins by receptor stimulation, significantly attenuated rERG inhibition by TRH. However, the presence of $G \alpha_{t}$ did not appear to alter the TRH-induced shifts in hERG activation voltage dependence in HEK-H36/T1 cells, a permanently transfected HEK-293 cell line showing high hERG current densities and consistent hormonal responses following activation of the TRH-Rs also introduced in the cells [40]. As an initial step to confirm the existence of differences in the transduction cascade coupling the TRH-R to ERG channels regulation as a function of the cell type, we compared the TRH effects on ERG currents in the presence and the absence of the $\mathrm{COOH}$-terminal part of $\beta$-adrenergic receptor kinase $(\beta$ $\mathrm{ARK} / \mathrm{CT}$ ), an agent able to effectively bind and sequester free $\beta \gamma$ complexes when dissociated from $\mathrm{G} \alpha$ subunits upon receptor stimulation [34]. Only cells identified by fluorescence of EGFP used as a reporter of transfection were selected for recording. We also used perforated-patch conditions to minimize cell dialysis and to preserve intact the intracellular components necessary for the hormonal response.

Thus, we first quantified the strong and reproducible rERG current reductions triggered by TRH in $\mathrm{GH}_{3}$ cells measuring the total inward charge elicited during the hyperpolarizing pulses (see the "Materials and methods" section and [40] for details). Due to the strong TRH-induced diminution of the current magnitude and the need to perform a subtractive method for isolation of the endogenous rERG current (see below), we found technically unsuitable to perform a direct and accurate comparison of the current activation voltage dependence in the presence and the absence of the hormone, particularly in cells previously subjected to transfection. However, it has previously been shown that the charge reductions are due to a rightward shift in activation voltage dependence combined with a relatively small reduction of maximal current density at positive potentials [33]. In this case, isolation of the endogenous rERG current present in $\mathrm{GH}_{3}$ cells and quantification of its TRH-induced inhibition was performed in high- $\mathrm{K}^{+}$low- $\mathrm{Ca}^{2}$ ${ }^{+}$extracellular solutions using hyperpolarization pulses to $-100 \mathrm{mV}$ from a depolarized holding potential of $-10 /$ $-20 \mathrm{mV}$. As previously reported, these conditions would increase the otherwise inwardly rectifying ERG currents, reducing the $\mathrm{Ca}^{2+}$ currents and the subsequent activation of the $\mathrm{Ca}^{2+}$-dependent $\mathrm{K}^{+}$currents also present in these cells $[3,6,8]$. Furthermore, $5 \mu \mathrm{M}$ of the ERG-specific blocker E4031 was added at the end of each experiment to totally block the rERG currents and to subtract the E-4031insensitive current, allowing quantification of the TRH effects exclusively on the rERG currents in every individual cell $[23,40,56]$. This subtractive method allowed for comparison of the TRH effects on the rERG current of $\mathrm{GH}_{3}$ cells transfected with or without $\beta \gamma$ dimer scavengers (Fig. 1). It can be observed that, analogous to the results observed with $\mathrm{G} \alpha_{\mathrm{t}}$ (Fig. 1 and [40]), the inhibition of rERG by TRH was attenuated from $76.8 \pm 3.5 \%(n=4)$ in control cells to $35.5 \pm$ $7.2 \%(n=6)$ in the presence of $\beta$ ARK/CT $(p<0.005)$. As final confirmation that free $\beta \gamma$ dimers are indeed necessary for the TRH effects in $\mathrm{GH}_{3}$ cells, we also used phosducin, another agent known to bind free $\beta \gamma$ dimers with high affinity, blocking their action [12]. In this case, the TRHinduced inhibition of the $\mathrm{GH}_{3}$ rERG was reduced to $37.2 \pm$ $3.6 \%(n=6, p<0.001)$ in $\mathrm{GH}_{3}$ cells overexpressing phosducin (Fig. 1). Interestingly, the impairment of the TRHinduced inhibition of the currents caused by the $\beta \gamma$ dimer scavengers was not paralleled by a similar antagonization of the accelerations in deactivation kinetics promoted by the hormone at $-100 \mathrm{mV}$. Thus, whereas in control cells the 230 

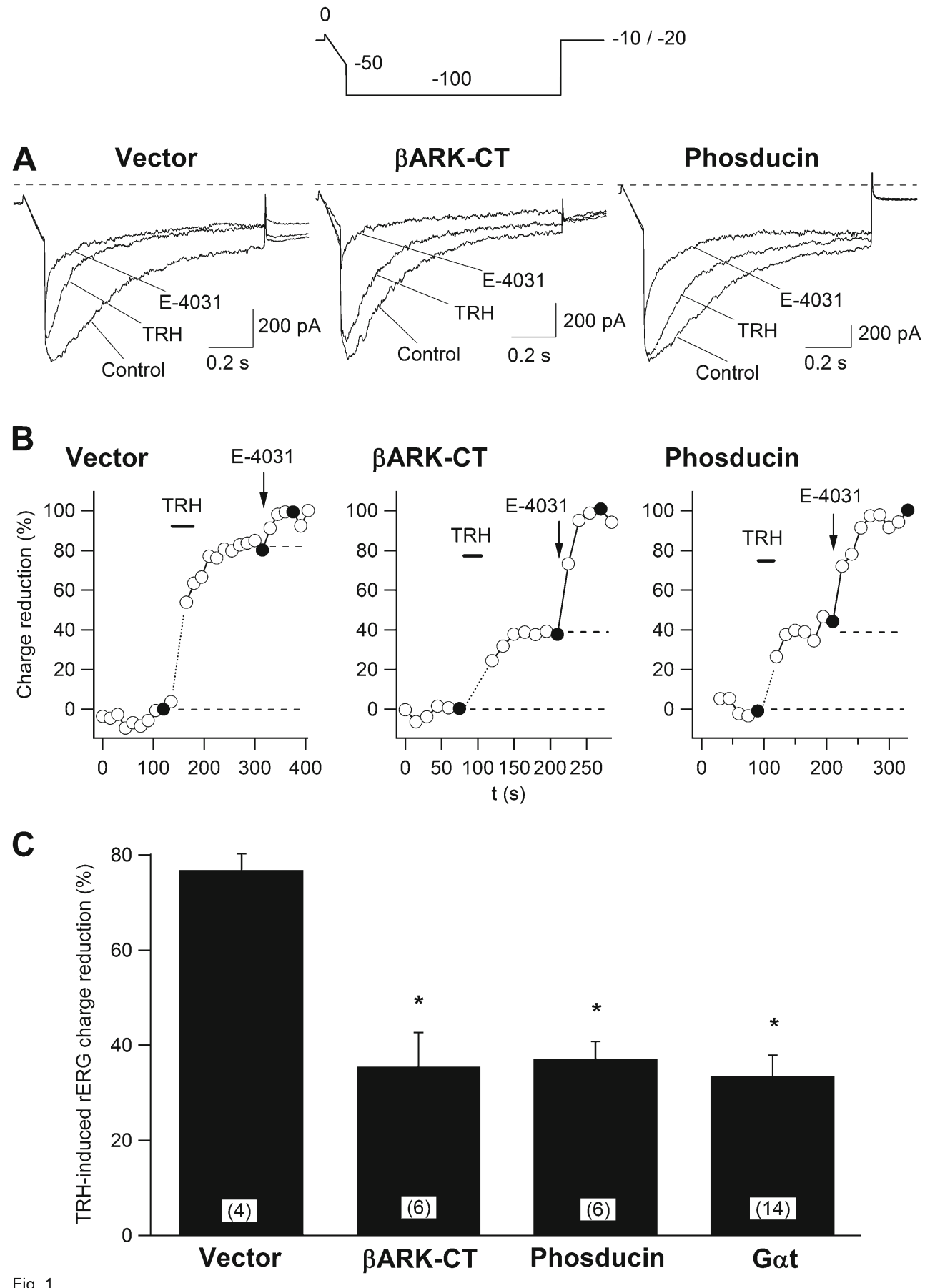

Fig. 1

Fig. 1 G protein $\beta \gamma$ dimer scavengers decrease TRH-induced inhibition of endogenous rERG currents in $\mathrm{GH}_{3}$ cells. a Effect of TRH on rERG currents. Representative current traces are shown for three cells $48 \mathrm{~h}$ after transfection with vector pcDNA.3 or with plasmids encoding the $\beta \gamma$ scavengers $\beta$-ARK/CT and phosducin. Currents were elicited in response to the voltage protocol shown at the top. The hyperpolarization step was preceded by a $100-\mathrm{ms}$ ramp from 0 to $-50 \mathrm{mV}$ [23]. Superimposed traces correspond to those obtained before (Control) and after addition of $1 \mu \mathrm{M}$ TRH and $5 \mu \mathrm{M}$ E-4031. For more details, see text. b Time course of the TRH and E-4031 effects. Current estimations were performed in the same cells as in panel a from total inward charge during the hyperpolarization steps at $-100 \mathrm{mV}$ as described in the "Materials and methods" section. Averaged charge values before any addition and after adding $5 \mu \mathrm{M} \mathrm{E}$ 4031 were considered as $0 \%$ and $100 \%$, respectively. Filled circles correspond to the current traces shown in a. The first or first and second data points after starting the TRH addition, when total inward currents become transiently enhanced by activation of $\mathrm{Ca}^{2+}$-dependent $\mathrm{K}^{+}$channels due to massive liberation of $\mathrm{Ca}^{2+}$ from intracellular stores, have been deleted for clarity. Duration of TRH perfusion and addition of E-4031 to the recording chamber are indicated with a thick line and an arrow, respectively. Current levels in the absence and presence of TRH are indicated by horizontal dashed lines. The $Y$-axis label on the left applies to the three panels. $\mathbf{c}$ Averaged percentages of rERG current inhibition induced by TRH in $\mathrm{GH}_{3}$ cells transfected with $\beta \gamma$ scavengers. Data corresponding to $\beta$-ARK/CT, phosducin, and $\mathrm{G} \alpha_{\mathrm{t}}$ are shown and compared with those from cells transfected with pcDNA.3. Current inhibitions were estimated from total inward charge as described in $\mathbf{b}$. ${ }^{*} p<0.05$ vs. control vector 
$\pm 23 \mathrm{~ms}$ deactivation time constant was reduced by TRH to $123 \pm 10 \mathrm{~ms}(n=4 ; p<0.01)$, these values amounted $234 \pm 16$ and $156 \pm 15 \mathrm{~ms}(n=6 ; p<0.01)$ in cells transfected with $\beta A R K / C T$. Furthermore, in cells expressing phosducin, the deactivation time constants corresponded to $292 \pm 37$ and $164 \pm 30 \mathrm{~ms}(n=6 ; p<0.02)$ in the absence and the presence of TRH, respectively.

It is important to note that, as reported for $G \alpha_{t}$ [40], the inhibitory effects of $\beta$-ARK/CT and phosducin are specific for the TRH-induced reduction of the rERG currents, because the elevations in $\left[\mathrm{Ca}^{2+}\right]_{i}$ triggered by the hormone remained unaltered in the cells transfected with the $\beta \gamma$ dimer scavengers (Suppl. Fig. 1). Thus, the addition of $1 \mu \mathrm{M}$ TRH to control cells only expressing the transfection marker EGFP elicited an initial peak of $\left[\mathrm{Ca}^{2+}\right]_{i}$ elevation that raised the cation from a basal averaged level of $124 \pm$ $2 \mathrm{nM}$ up to $253 \pm 44 \mathrm{nM}(n=13)$. These values amounted to $120 \pm 20$ and $221 \pm 20 \mathrm{nM}$, respectively, in the $\beta$-ARK/CTtransfected cells $(n=13)$. Finally, the basal $115 \pm 1 \mathrm{nM}\left[\mathrm{Ca}^{2}\right.$ $\left.{ }^{+}\right]_{i}$ was raised to an initial peak of $257 \pm 20 \mathrm{nM}(n=18)$ after adding TRH to the $\mathrm{GH}_{3}$ cells transfected with phosducin. Interestingly, these hormone-induced $\left[\mathrm{Ca}^{2+}\right]_{i}$ increases were almost the same than those observed in the cells from the same plates in which the presence of the transfection marker was not detected (YFP - in supplementary Fig. 1).

To confirm the presence of differences in the TRHinduced effects related to cell type, we performed experiments with human HEK-H36/T1 cells similar to those in rat adenohypophysial $\mathrm{GH}_{3}$ cells, measuring the rightward shift in hERG activation voltage dependence triggered by the hormone in the EGFP fluorescent cells. It has been repeatedly demonstrated that the native ERG current of $\mathrm{GH}_{3}$ cells is almost undetectable using external solutions with physiological levels of $\mathrm{K}^{+}$, and that careful formulation of the high- $\mathrm{KCl}$ recording medium and the recording protocols is necessary for native ERG isolation from other endogenous currents $[3,6,8,23,33,40,47,48,56]$. However, our attempts to extrapolate such conditions to hERG recordings using HEK-H36/T1 cells were hampered by the systematic appearance of huge E-4031-insensitive currents when the extracellular $\mathrm{K}^{+}$concentration was increased (e.g. to 40 or $140 \mathrm{mM}$ both plus and minus EGTA). Therefore, the standard extracellular saline with low $\mathrm{mM}$ levels of $\mathrm{K}^{+}$and $\mathrm{Ca}^{2+}$ was used for recordings in these cells. As shown in Fig. 2, addition of TRH to cells transfected with a control pcDNA3 vector (without any $\beta \gamma$ scavenger) induced a rightward shift of the hERG I/V curve that amounted to $21.3 \pm 1.1 \mathrm{mV}$ ( $n=$ $8)$. This shift remained the same in the $\beta$-ARK/CT-transfected cells $(21.8 \pm 2.0 \mathrm{mV}, n=7)$. As stated in the legend of Fig. 2, the steepness of the activation curves was not significantly modified by the hormone either in the absence or the presence of the scavenger. It is interesting to note that the presence of the $\beta \gamma$ scavenger did not also impair the ability of the hormone to accelerate tail currents decay. Fitting a biexponential function to the decaying tail current phase at $-50 \mathrm{mV}$ yielded fast and slow deactivation time constants of $138 \pm 11$ and $973 \pm 114 \mathrm{~ms}(n=7)$ in the $\beta$-ARK/CT-transfected cells before TRH addition. These values were reduced by the hormone to $94 \pm 11$ and $627 \pm 65 \mathrm{~ms}$ ( $p<$ $0.05)$, respectively. This behaviour paralleled that observed in control cells without $\beta$-ARK/CT, showing fast and slow deactivation time constants of $136 \pm 13$ and $775 \pm 46 \mathrm{~ms}(n=$ 5), that were reduced by TRH to $85 \pm 6$ and $460 \pm 30 \mathrm{~ms}$ ( $p<$ 0.01 ).

It seems unlikely that failure to modify these TRHinduced effects was due to lack of efficient expression of $\beta$-ARK/CT in these cells, since they showed much higher transfection efficiencies than those exhibited in the pituitary cells, in which the scavenger clearly reduced the hormone effects (see above). This interpretation is further supported by the data obtained with phosducin. In this case the activation voltage dependence shift amounted to $20.2 \pm 2.2 \mathrm{mV}$ $(n=4)$, a value again similar to that observed in the control cells (Fig. 2). Besides confirming the results previously obtained with $\mathrm{G} \alpha_{\mathrm{t}}$ (Fig. 2 and [40]) and $\beta$-ARK/CT, these data indicate that free $\beta \gamma$ dimers are not involved in the TRH-induced modulation of hERG kinetics in the HEKH36/T1 cells. Therefore, our results suggest that some cellular components involved in hormone action may vary as a function of the cell type in which they are taking place.

Effect of Akt/PKB-directed siRNAs on enzyme protein levels and TRH-induced modulation of ERG currents

It has been previously reported that basal activity of Akt/ protein kinase $\mathrm{B}$ (PKB) is required for normal function of hERG channels stably expressed in HEK293 cells [58]. Since an unknown kinase(s) activity has long been implicated in the transduction pathway from TRH-R to ERG channels [23], we studied the implication of Akt/PKB in this pathway performing experiments with siRNAs developed against the kinase.

To check whether the hormonal modulation of the rERG channels in $\mathrm{GH}_{3}$ cells was dependent on the presence of Akt/PKB, we initially generated an siRNA mixture designed to block the expression of the rat Akt/PKB genes from these cells, using the rat Akt1 mRNA stretch between positions 359 and 1427 as target. Note that this siRNA mixture is expected to interfere not only with the expression of rat Akt1, but also Akt2 and Akt3 genes, since they show identities of $79 \%$ and $71 \%$ to rat Akt1, respectively. As a negative control we used a pool of non-targeting siRNAs and as a positive control a mixture of siRNAs against the $\alpha$ subunit of the $\mathrm{G}_{\mathrm{q}}$ protein. Whereas the anti-G $\alpha_{\mathrm{q}}$ was very effective at minimizing the $\mathrm{G}_{\mathrm{q}}$-dependent and $\mathrm{IP}_{3}$-dependent initial $\left[\mathrm{Ca}^{2+}\right]_{i}$ elevations triggered by TRH in the $\mathrm{GH}_{3}$ cells 
Fig. 2 TRH-induced hERG modulation is not altered by $\beta \gamma$ scavengers in HEK-H36/T1 cells. a Representative current traces in response to the voltage protocol depicted at the top are shown for two cells transfected with pcDNA. 3 vector alone (Control) or with $\beta$-ARK/CT. Currents correspond to those recorded before (-TRH) and 2 min after adding $1 \mu \mathrm{M}$ TRH (+TRH). Note that the tail currents during the repolarization step to $-50 \mathrm{mV}$ almost exclusively correspond to those mediated by hERG channels, since they are largely abolished in the presence of E-4031 [40]. b Effect of $\beta$-ARK/CT on TRHinduced modifications of $\mathrm{hERG}$ activation voltage dependence. Averaged I/V curves normalized to maximum before TRH addition are shown for the number of indicated cells. $V_{1 / 2}$ values before and after adding TRH are indicated with arrows in the graphs. Similar steepness of the activation curves was observed upon TRH addition. Thus, the slope factor amounted $12.1 \pm 1.1$ and $11.3 \pm 0.9(n=8)$ with and without TRH in the control cells, and $12.1 \pm 0.6$ and $10.4 \pm 0.6(n=7)$ in the cells transfected with $\beta$-ARK/CT. The $Y$-axis label on the left applies to both panels. c Comparison of TRH-induced shifts in hERG activation voltage dependence in the presence of $\beta \gamma$ dimer scavengers
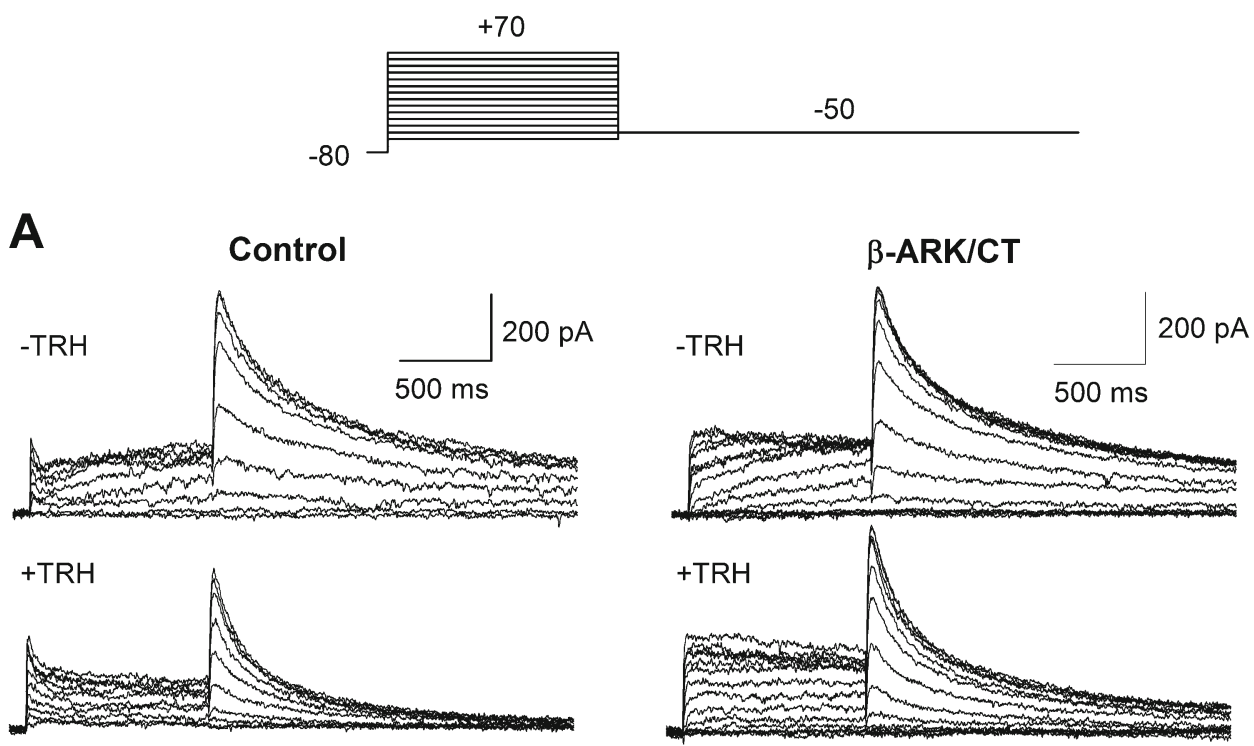

B

Control

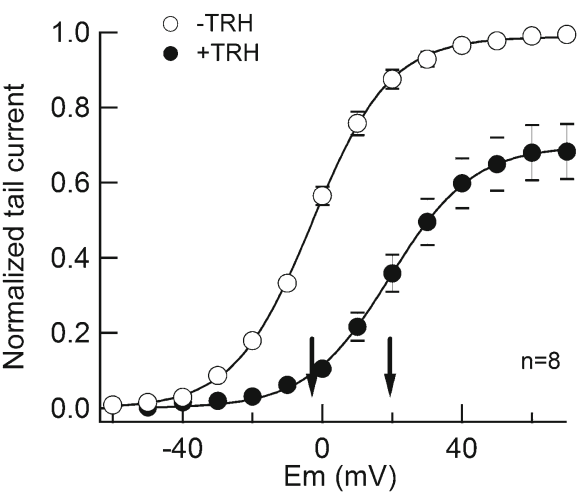

C

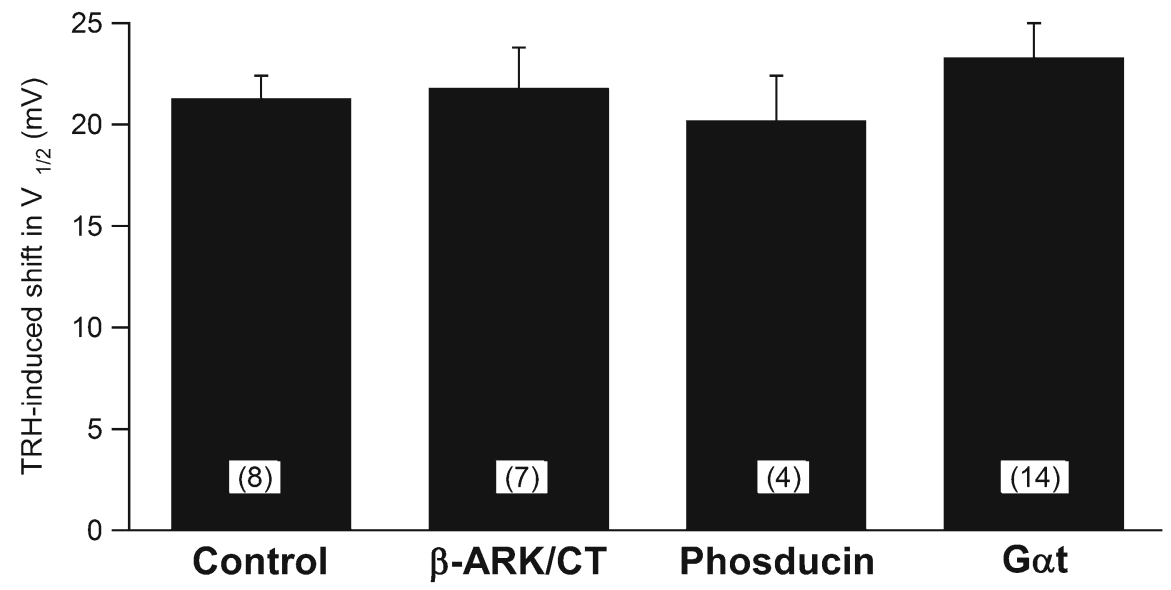

$\beta$-ARK/CT

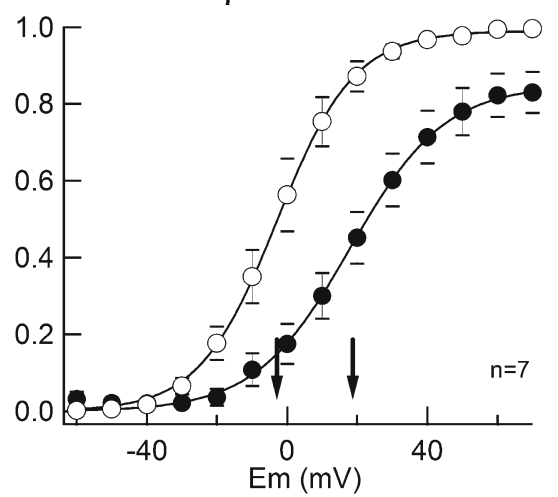

(4)

$\mathbf{G} \alpha \mathbf{t}$ (not shown), the inhibitions of the rERG currents induced by the hormone in these cells remained almost the same in the presence of up to $1 \mu \mathrm{g}$ of the siRNA mixture against Akt (Fig. 3). To confirm that this amount of silencing agent was effective at knocking Akt/PKB expression down, we estimated the protein levels by Western analysis. As for electrophysiological analysis, only successfully transfected cells, identified by their EGFP fluorescence and selected from the rest by a cell sorter, were used. This allowed us to detect a prominent reduction of the protein levels of the three rat Akt/PKB isoforms (Akt1 of $55.7 \mathrm{kDa}, \mathrm{Akt} 2$ of $55.5 \mathrm{kDa}$, and Akt3 of $55.8 \mathrm{kDa}$ ) in the presence of the anti-Akt/PKB siRNAs, close to $75 \%$ in cells transfected with $1 \mu \mathrm{g}$ of the siRNAs mixture (Fig. 3a). As confirmation that $\mathrm{Akt} / \mathrm{PKB}$ expression is not involved in the hormonal inhibition of rERG in the $\mathrm{GH}_{3}$ cells, we also used a specific 
Fig. 3 Knockdown of Akt/ PKB does not interfere with rERG regulation by TRH in $\mathrm{GH}_{3}$ cells. a Blockade of Akt/ PKB expression by siRNAs in EGFP positive $\mathrm{GH}_{3}$ cells. Cells were transfected with $1 \mu \mathrm{g}$ of non-targeting (n.t.) siRNAs, $1 \mu \mathrm{g}$ of anti-rat Akt1 siRNAs mix, or $1 \mu \mathrm{g}$ of anti-rat Akt1 siRNA 112 , plus $1 \mu \mathrm{g}$ of pEGFP-C1 in each case, and after $48 \mathrm{~h}$ selected with a FACStar Plus Cell Sorter. Cell extracts were separated by $10 \%$ SDS-PAGE and subjected to immunodetection with anti-Akt and anti-GAPDH antibodies. b Effect of TRH on $\mathrm{GH}_{3}$ cell rERG currents in the presence of anti-Akt siRNAs. Representative current traces from one cell transfected with $1 \mu \mathrm{g}$ of anti-Akt siRNA mix are shown on the left. Currents were recorded as indicated in Fig. 1 before and after addition of $1 \mu \mathrm{M}$ TRH and $5 \mu \mathrm{M}$ E-4031. Monoexponential fits to the decaying phase of the currents at $-100 \mathrm{mV}$ after subtracting the current remaining in the presence of E-4031, yielded deactivation constants of 258 and $150 \mathrm{~ms}$ before and after adding TRH, respectively. The time course of the TRH and E-4031 effects in the same cell is shown on the right. Filled circles correspond to the current traces shown on the right. c Averaged percentage of rERG current inhibition induced by TRH in $\mathrm{GH}_{3}$ cells transfected with $1 \mu \mathrm{g}$ of non-targeting siRNAs, antirat Akt siRNA mix, or anti-rat Akt1 specific 1112 siRNA

A

siRNAs n.t. mix 1112

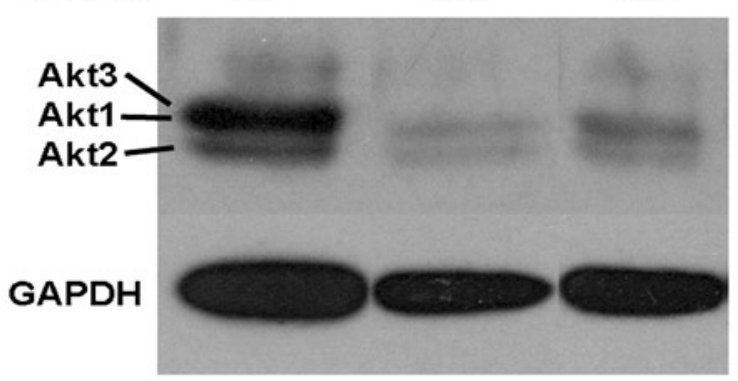

B $1 \mu \mathrm{g}$ siRnAs mix
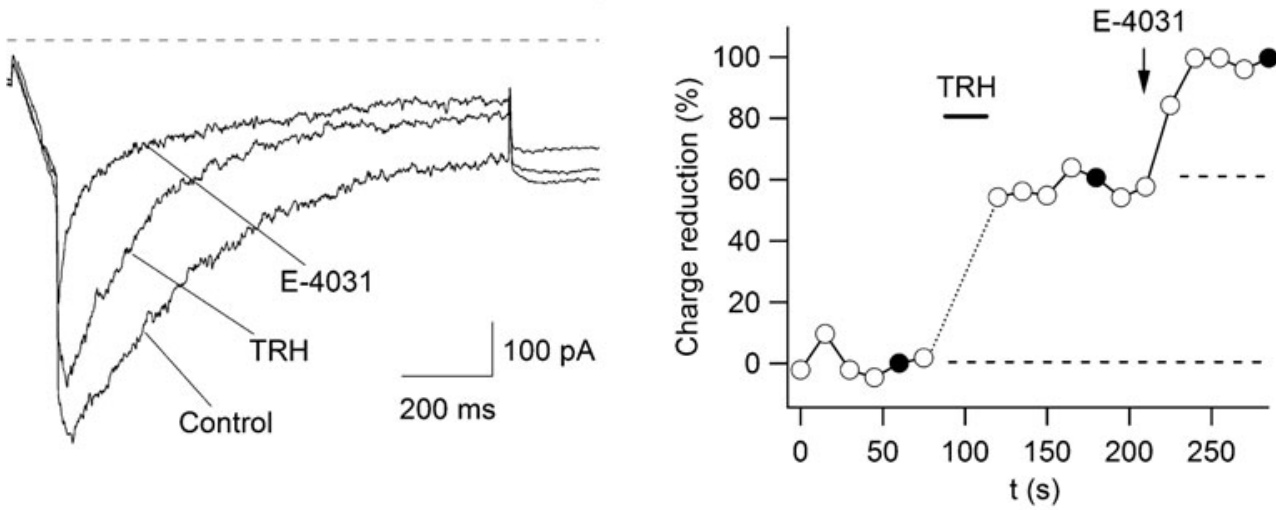

C

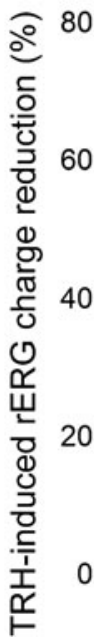

$0 \perp$ n.t.

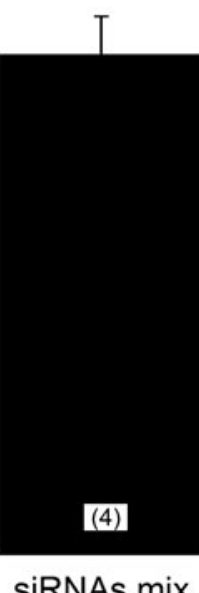

siRNAs mix

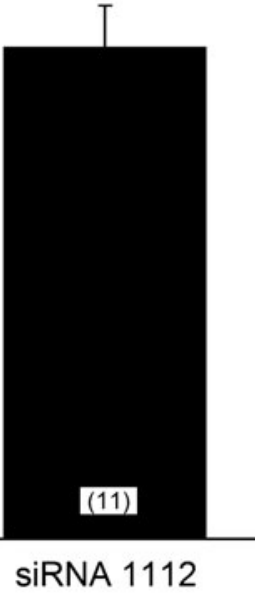

siRNA (named 1112) directed against the sequence of rat Akt1. In this case, equivalent results to those obtained with the siRNA mix were observed, since although similar reductions in the level of Akt expression were elicited in cells transfected with $1 \mu \mathrm{g}$ of 1112 siRNA, an averaged rERG current inhibition of $71.36 \pm 6 \%(n=11)$ was induced by TRH in the cells treated with this amount of the silencing agent (Fig. 3)

To check for possible differences as a function of the cell type, we also studied the implication of Akt/PKB in the response to TRH in HEK-H36/T1 cells. We therefore prepared an siRNA mix against human Akt1 mRNA (from positions 1339 to 2105), intended to block the expression of the Akt/PKB genes in HEK-H36/T1 cells, and the knockdown of Akt/PKB expression was assessed by western blot (Fig. 4). As shown in Fig. 4a, a reduction of the three Akt/ PKB isoforms described in human cells (Akt1 of $65 \mathrm{kDa}$, Akt2 of $60 \mathrm{kDa}$, and Akt3 of $58 \mathrm{kDa}$ ) is clearly induced by the siRNAs mixture that produced a marked decrease in protein levels when transfecting with $500 \mathrm{ng}$ of siRNAs. Despite the fact that the mix was directed against Aktl, the decrease is also observed in the Akt2/Akt3 bands, which could be due to the fact that Akt2 and Akt 3 show $80 \%$ and $72 \%$ identity to Akt1, respectively. 
A

siRNAs

n.t.

mix

501

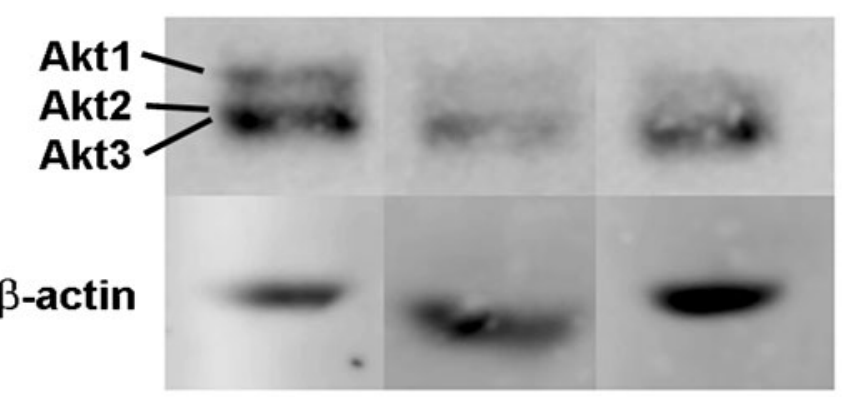

B

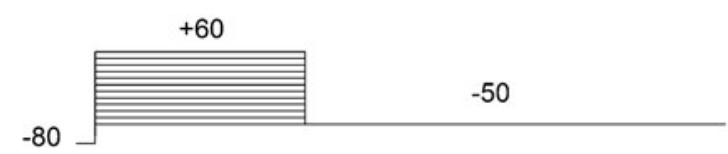

- TRH

$500 \mathrm{ng}$ siRNAs mix

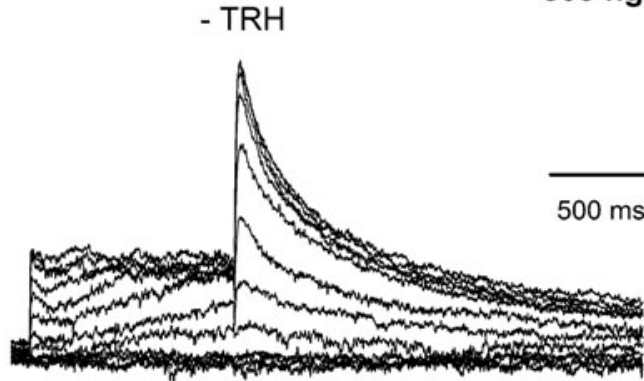

$200 \mathrm{pA}$

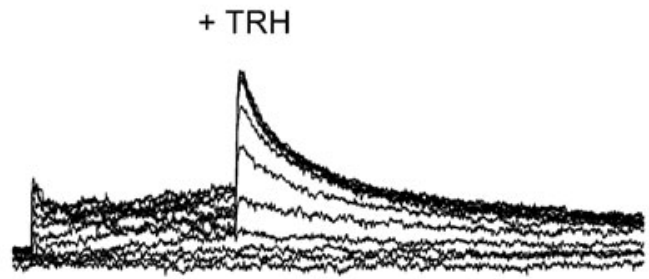

C

non-targeting

SiRNAs mix

SIRNA 501

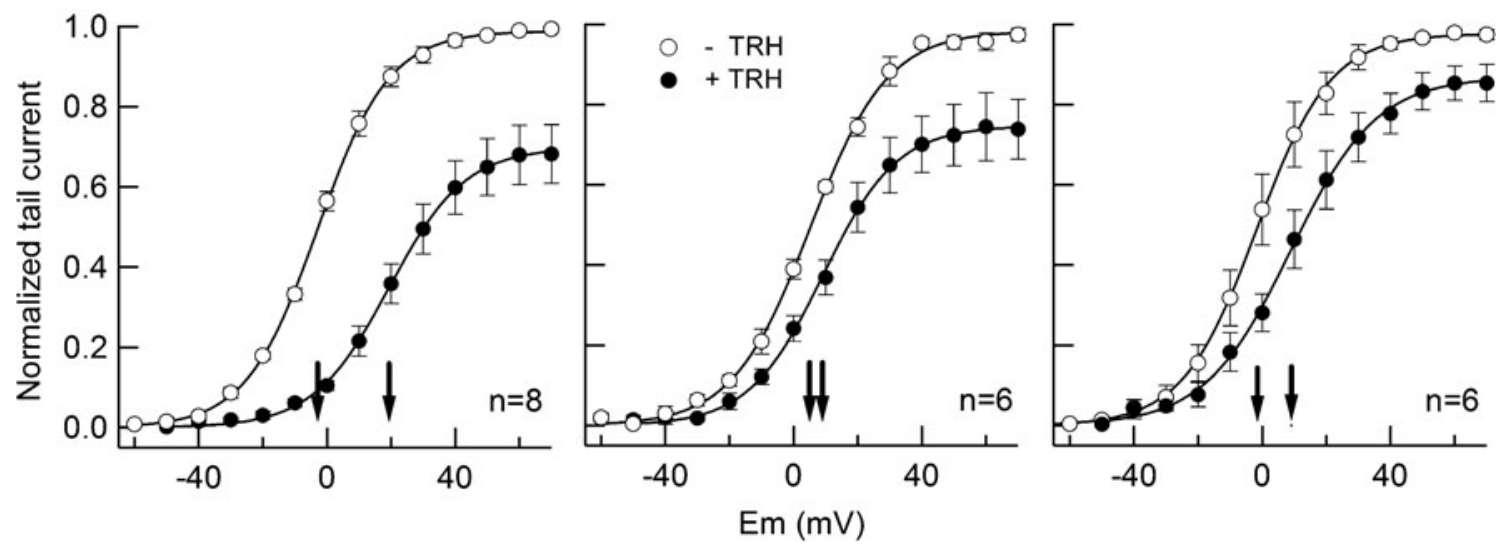

Fig. 4 Knockdown of Akt/PKB blocks hERG regulation by TRH in HEK-H36/T1 cells. a Blockade of Akt/PKB expression by siRNAs in HEK-H36/T1 cells. Cells were transfected with $1 \mu \mathrm{g}$ of non-targeting (n.t.) siRNAs, $0.5 \mu \mathrm{g}$ of anti-human Akt siRNA mix or $1 \mu \mathrm{g}$ of antihuman Akt1 siRNA 501. Cell extracts were separated by $8 \%$ SDSPAGE and subjected to immunodetection with anti-Akt and anti- $\beta$ actin antibodies. b Effect of TRH on hERG currents in the presence of anti-Akt siRNAs. Representative currents from one cell transfected with $500 \mathrm{ng}$ of siRNA mix (left) or $1 \mathrm{mg}$ of siRNA 501 (right), before $(-\mathrm{TRH})$ and after $(+\mathrm{TRH})$ adding $1 \mu \mathrm{M}$ TRH. The voltage protocol

The efficacy of the siRNA mixture in suppressing Akt/ PKB expression in HEK-H36/T1 cells prompted us to check used to elicit the currents is shown at the top. c Effect of anti-Akt siRNAs on TRH-induced modifications of hERG activation voltage dependence. Averaged I/V curves normalized to maximum before TRH addition are shown for cells transfected with siRNAs nontargeting $(1 \mu \mathrm{g})$, anti-Akt mix $(0.5 \mu \mathrm{g})$, or $501(1 \mu \mathrm{g})$. The slope factors of the curves in the cells transfected with the siRNAs mix amounted $12.0 \pm 0.9$ and $11.5 \pm 0.9(n=6)$ without and with TRH, respectively. These values corresponded to $11.2 \pm 0.3$ and $12.4 \pm 0.5$ ( $n=$ 6 ) in the siRNA 501-containing cells. The $Y$-axis label on the left applies to the three panels

the effects of TRH-R stimulation on hERG currents in the siRNA-transfected cells. Again, only successfully 
transfected cells identified by their EGFP fluorescence were selected for recording. As shown in Fig. 4b, c, the shift to more positive voltages caused by TRH in the hERG I/V curve when siRNAs had not been added to the cells ( $21.3 \mathrm{mV}$, see above), was drastically reduced both in cells transfected with $500 \mathrm{ng}$ of the anti-Akt1 siRNA mixtures (shift value $3.5 \pm 1.9 \mathrm{mV}, n=6 ; p<0.01$ ). The introduction of the silencing agent also impaired the ability of the hormone to accelerate tail current deactivation. Thus, the fast and slow deactivation time constants in the untransfected cells were $136 \pm 13$ and $775 \pm 46 \mathrm{~ms}(n=5)$ before and $85 \pm 6$ and $460 \pm 30 \mathrm{~ms}(p<0.01)$ after TRH treatment. On the other hand, whereas in the cells transfected with $500 \mathrm{ng}$ of siRNA the constants amounted to $152 \pm 28$ and $824 \pm 43 \mathrm{~ms}(n=3)$ without TRH treatment, no significant alterations of these values were observed upon hormone addition to the cells, that showed values of $132 \pm 13$ and $727 \pm 73 \mathrm{~ms}$. Interestingly, the antagonization of the TRH effect by anti-PKB siRNAs was less marked on the relatively small current reductions induced by the hormone in these cells, since maximal peak tail currents were lowered by TRH $36.2 \pm$ $4.4 \%(n=8)$ in non-transfected cells, whereas TRH addition produced $24.6 \pm 4.0 \%(n=6, p=0.08)$ smaller peak tail currents in cells transfected with 500 ng of siRNA. To confirm that the effect of the siRNA mix was indeed due to the knockdown of Akt/PKB expression and not to an offtarget action on other gene(s) due to the multitude of different siRNAs present in the mix, we designed and used the siRNA 501, specific for the sequence of human Akt1 mRNA. Cells transfected with $1 \mu \mathrm{g}$ of this siRNA showed an effective and specific block of Akt1 expression (Fig. 4a), and also an impaired response to TRH, since the hERG current shift in activation voltage dependence was reduced to $10.4 \pm 1.9 \mathrm{mV}(n=6, p<0.05$; Fig. $4 \mathrm{c})$.

It is important to note that, as expected, the influence of the interference agent impairing the TRH effect is exerted in a component of the signalling cascade distal to the receptor itself, since the TRH-R coupling to $\mathrm{G}_{\mathrm{q} / 11}$ leading to elevations of intracellular $\mathrm{Ca}^{2+}$ upon TRH addition [40] remained unaltered in the presence of anti-Akt siRNA. Thus, the initial peak of $\left[\mathrm{Ca}^{2+}\right]_{i}$ elevation induced by TRH in untransfected Fura-2loaded HEK-H36/T1 cells increased the cation levels from 39 \pm 1 to $198 \pm 3 \mathrm{nM}(n=35, N=2)$. Almost identical results were obtained in the siRNA-transfected cells: the $\left[\mathrm{Ca}^{2+}\right]_{i}$ increased from $39 \pm 2$ to $183 \pm 6 \mathrm{nM}(n=39, N=3)$ in cells in which fluorescence of the transfection marker EGFP was detected, and from $35 \pm 2$ to $173 \pm 11 \mathrm{nM}(n=11, N=3)$ in the cell subpopulations in which EGFP fluorescence was negligible.

The fact that Akt/PKB presence is essential for the transduction of the TRH signal in HEK-H36/T1 but not in $\mathrm{GH}_{3}$ cells emphasizes again the influence of the cell type on the molecular mechanisms used by the hormone to modulate ERG channel functionality.
Cell-dependent effect of pharmacological blockade of Akt/ PKB activation on TRH-induced ERG modulation

The results presented above strongly suggest that $\mathrm{Akt} / \mathrm{PKB}$ is involved in TRH modulation of hERG currents in HEK-H36/ T1 cells. Even though potent and specific inhibitors of Akt/ PKB are not available, the participation of PI3K in the signalling cascade linking different stimuli to Akt/PKB activation has been firmly established [13, 24, 26]. Therefore, we used wortmannin to inhibit PI3K activation and thereby the downstream PI3K-dependent Akt/PKB activation in HEK-H36/T1 cells. The effects of the inhibitor were assessed following a 5min incubation of the patch-perforated cells prior to TRH addition. The results in Fig. 5 show that in the presence of $100 \mathrm{nM}$ wortmannin the TRH-induced shift in the hERG I/V curves is strongly reduced [from $21.3 \mathrm{mV}$ in controls to $4.6 \pm$ $1.8 \mathrm{mV}(n=4)$ with wortmannin; $p<0.01]$. Almost identical results were obtained increasing the wortmannin level to $10 \mu \mathrm{M}$, a concentration at which not only PI3K, but also $\mathrm{PIP}_{2}$ resynthesis by phosphatidylinositol 4-kinase is impaired [42]. These results contrast with our previous data demonstrating that treatment of $\mathrm{GH}_{3}$ cells with up to $10 \mu \mathrm{M}$ wortmannin does not modify the TRH-induced inhibition of the endogenous rERG currents [23]. They also indicate that, unlike the results obtained in the HEK-H36/T1 cells heterologous expression system, Akt/PKB activity is not necessary for TRH effects in native $\mathrm{GH}_{3}$ cells. Finally, they further suggest that the cell specific protein composition/availability can indeed modulate which elements in the signal transduction pathways are involved in the TRH response.

Hormonal activators of Akt/PKB impair the ability of TRH to modulate ERG channels in a cell-dependent way

As additional confirmation that the influence of wortmannin and siRNAs blocking the TRH effect on ERG in HEK-H36/ T1 but not in $\mathrm{GH}_{3}$ cells is due to impairment of Akt/PKB action, we studied the TRH-induced shifts in hERG activation voltage dependence following treatment of the cells with insulin, a potent and very well-known physiological

Fig. 5 Abolishment of TRH-induced modulation of in HEK-H36/T1 hERG channel modulation by wortmannin. a Representative currents in response to the voltage protocol shown at the top before (Control), 5 min after treatment with $100 \mathrm{nM}$ wortmannin (wortmannin), and in the presence of wortmannin plus $1 \mu \mathrm{M}$ TRH (wort + TRH). b Elimination of the TRH-induced modulation of hERG activation voltage dependence in the presence of low $(100 \mathrm{nM})$ and high $(10 \mu \mathrm{M})$ concentrations of wortmannin. The $Y$-axis label on the left applies to the three panels. c Quantification of the wortmannin and wortmannin plus TRH effects on hERG activation voltage dependence. Note the small but not significant left shift in the I/V curves induced by wortmannin, and also that the shift values in the presence of TRH plus wortmannin refer to the displacement of the curves respect to those elicited in the presence of the inhibitor alone 
A

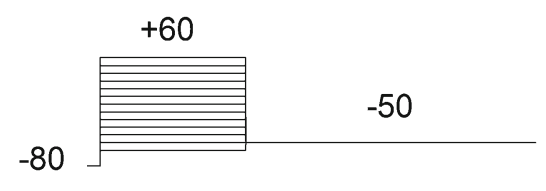

Control

Wortmannin

Wort + TRH
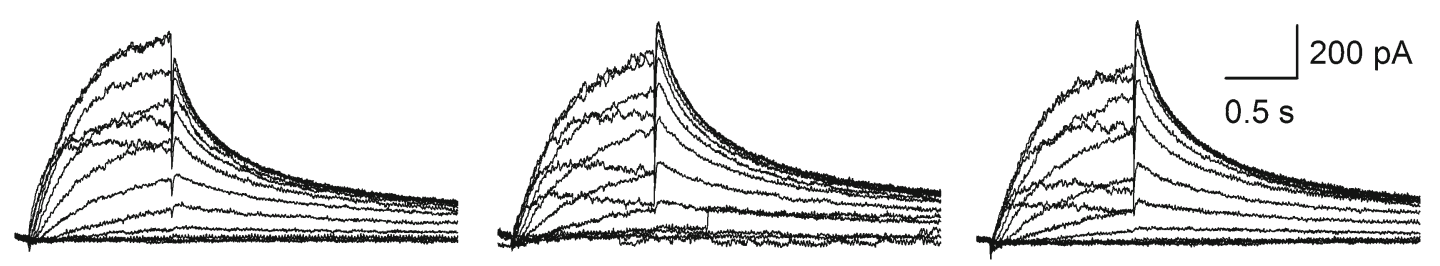

B
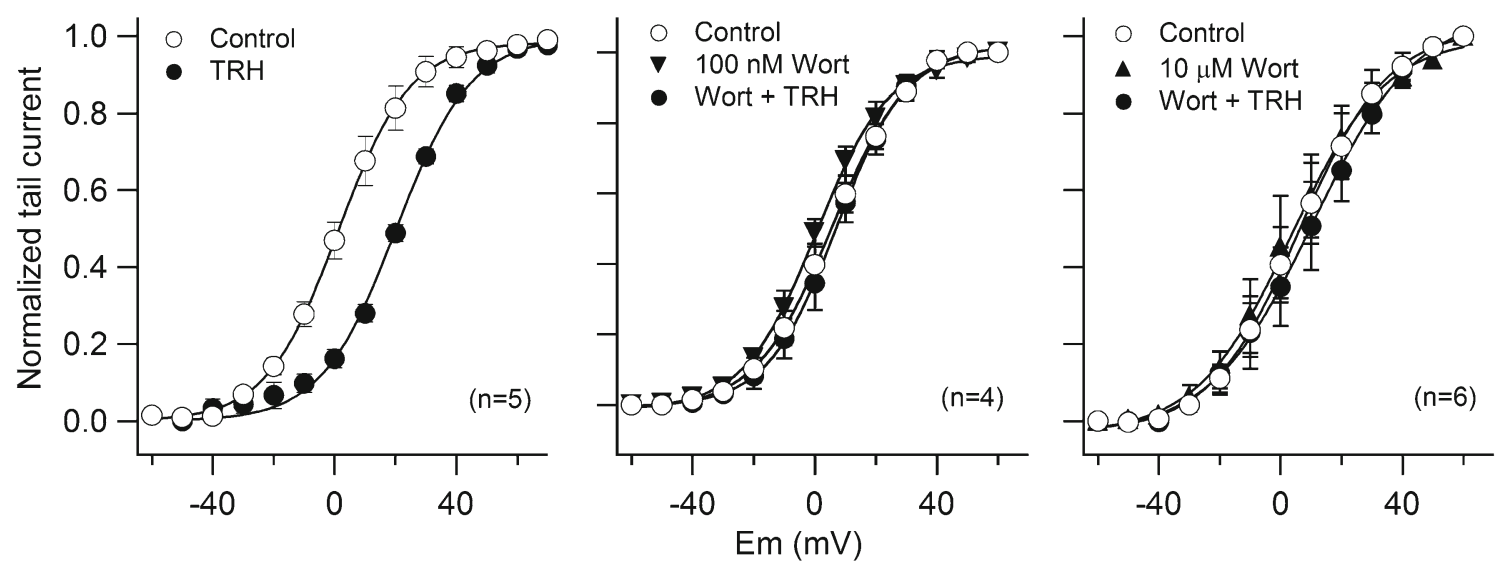

C

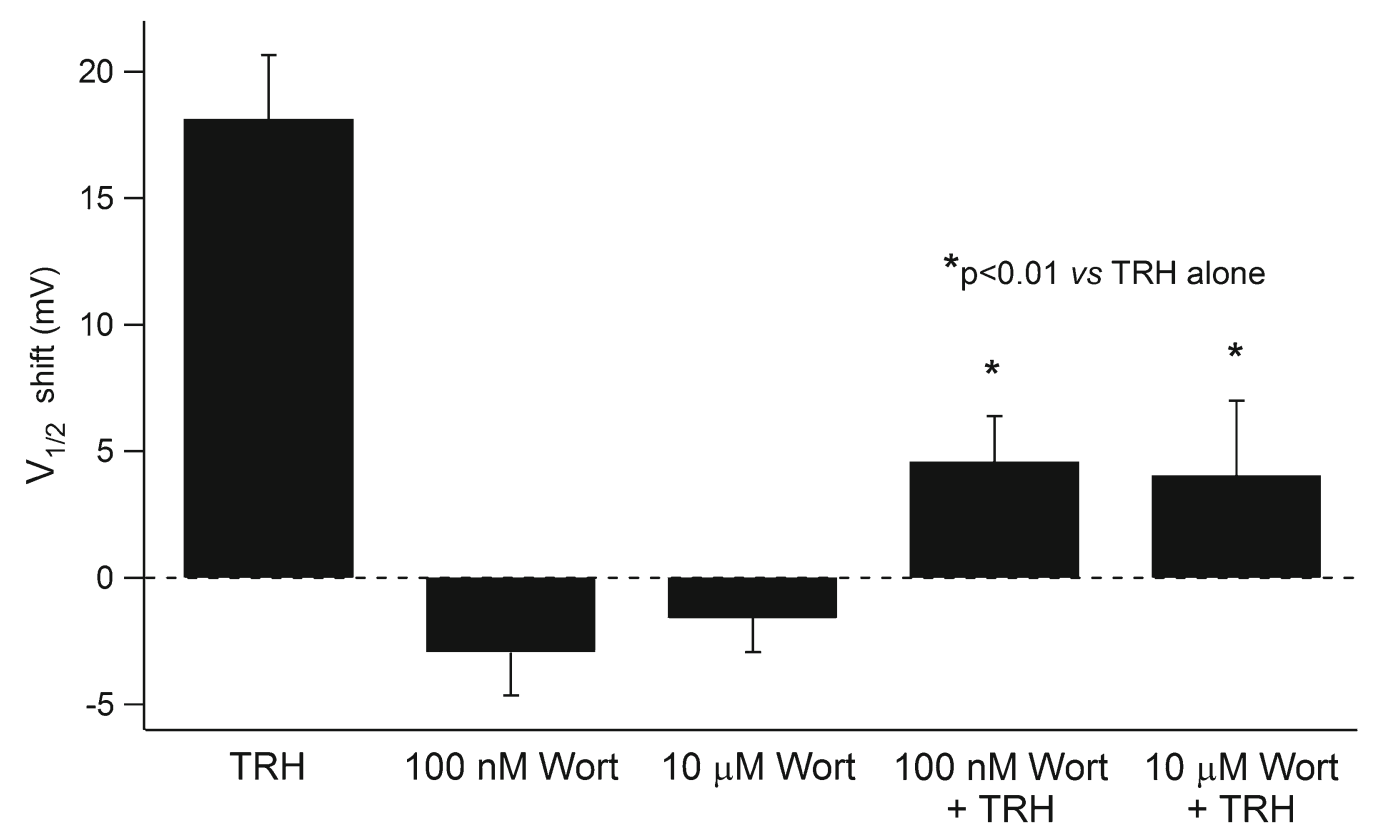

activator of the PI3K-Akt signalling cascade in a variety of cells $[13,21,29]$. In these experiments, $1 \mu \mathrm{M}$ insulin was used to ensure proper and complete activation of Akt/PKB through either the insulin receptor or the IGF-1 receptor that have been co-localized in HEK293 cells [11, 35]. In HEK$\mathrm{H} 36 / \mathrm{T} 1$ cells, the $V_{1 / 2}$ value of the isochronal $\mathrm{I} / \mathrm{V}$ curves for 
Fig. 6 Cell-selective blockade of TRH-induced regulation of ERG currents by long-term treatment with insulin. a Quantification of insulin and TRH effects on activation voltage dependence shifts of HEK-H36/ T1 cell hERG currents. Note that the shift values in the presence of TRH plus insulin refer to the rightward displacement of the curves respect to those elicited in the presence of insulin alone. b Effect of insulin and insulin plus TRH treatment on $\mathrm{GH}_{3}$ cell rERG currents. c Time course of insulin and TRH effects on $\mathrm{GH}_{3}$ cell rERG currents. Filled circles correspond to the current traces shown in panel $\mathbf{b}$. Values of total inward charge (see the "Materials and methods" section) respect to that measured in the presence of E-4031 are represented vs time. d Quantification of the insulin effect on TRH-induced inhibition of $\mathrm{GH}_{3}$ cell $\mathrm{rERG}$ currents
A

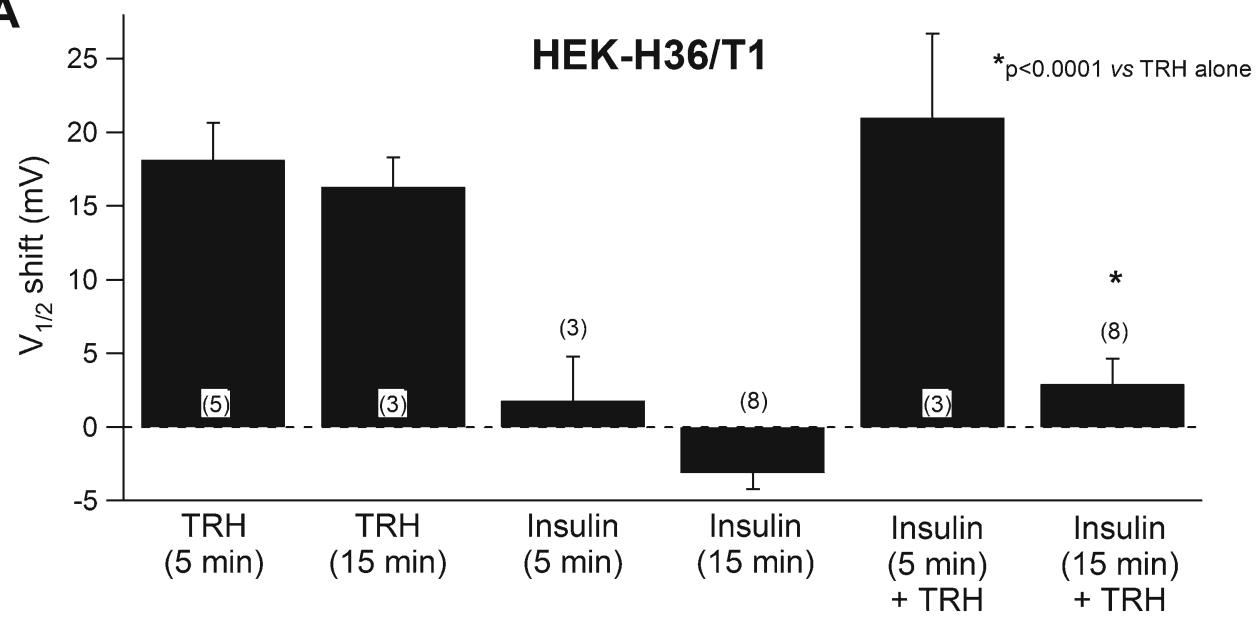

B
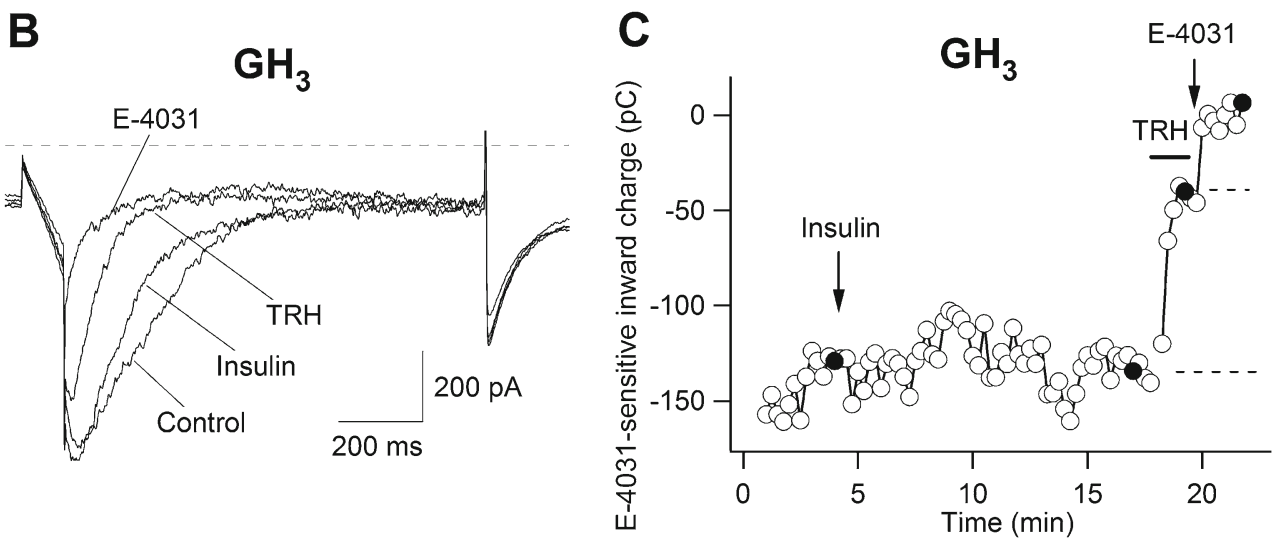

D

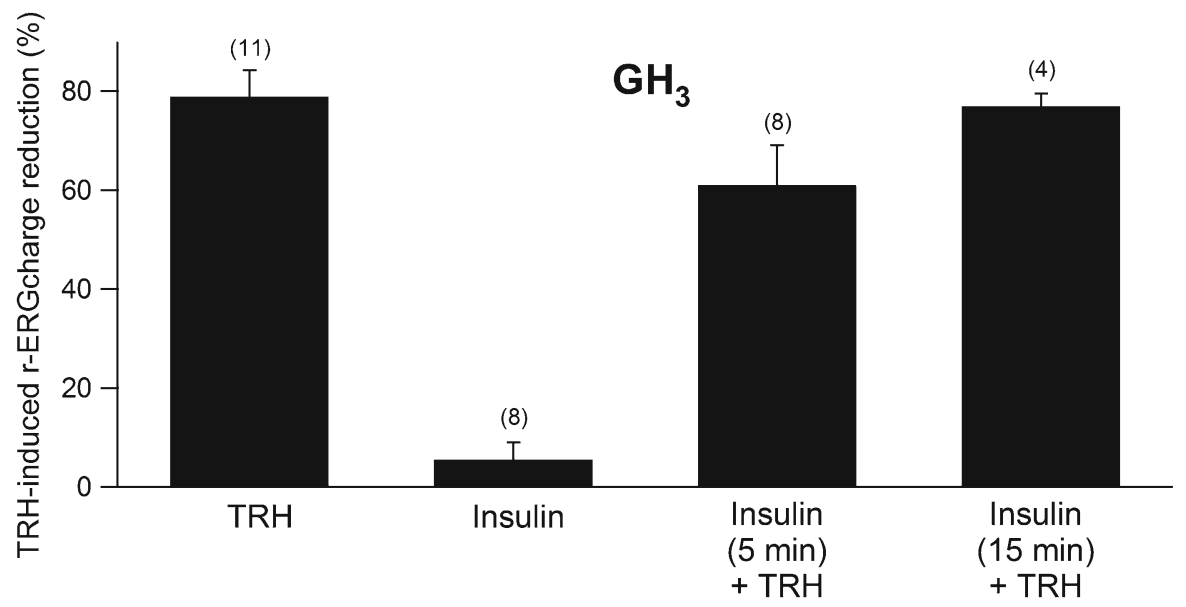

hERG activation remained unaltered following exposure to insulin for 5 or 15 min (Fig. 6a). However, whereas a normal rightward shift in activation voltage dependence was still observed when adding TRH after a 5-min insulin treatment (averaged shift value $21.0 \pm 5.7 \mathrm{mV}, n=3, p=$ $0.93)$, the TRH-induced displacement of the I/V curves was nearly abolished in cells exposed to insulin for a longer period of $15 \mathrm{~min}(2.9 \pm 1.7 \mathrm{mV}$ shift, $n=8, p<0.0001)$.

As shown in Fig. 6b-d, the reduction of the E-4031sensitive current induced by TRH in $\mathrm{GH}_{3}$ cells $(78.9 \pm$
$5.4 \%, n=11$ ) was not significantly altered when they were previously incubated with $1 \mu \mathrm{M}$ insulin for $5 \mathrm{~min}(61.0 \pm$ $8.1 \%, n=8 ; p=0.07$ ), even though maximum Akt/PKB activation in response to insulin has been observed in these cells under similar conditions [27]. Increasing the insulin treatment up to $15 \mathrm{~min}$ did not change the ability of TRH to inhibit rERG (77.0 $\pm 2.6 \%$ inhibition, $n=4 ; p=0.84)$. Almost identical results pertaining to insulin effects and TRH treatments were obtained using $\mathrm{GH}_{4} \mathrm{C}_{1}$ cells (data not shown), a cloned variant of the $\mathrm{GH}_{3}$ cells in which activation of the 


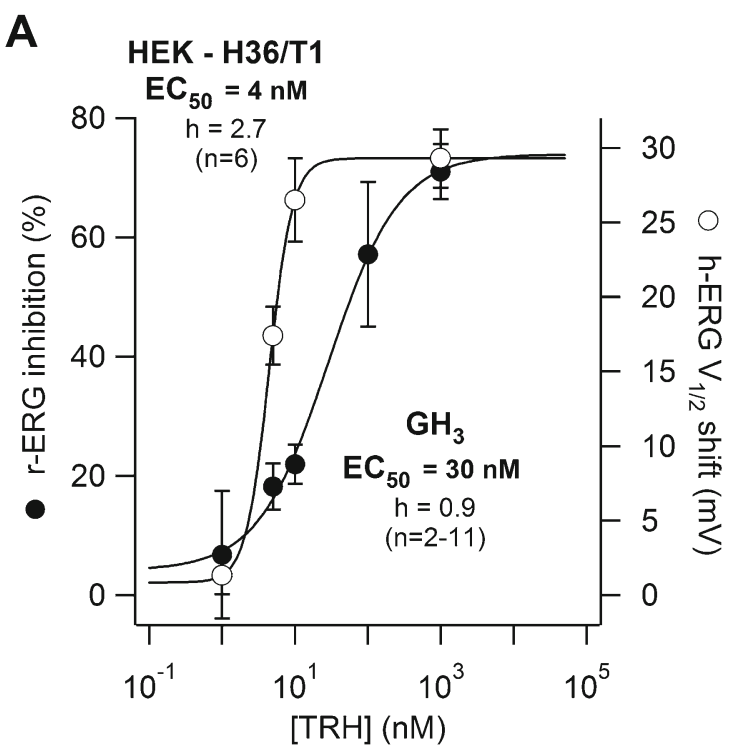

B

C

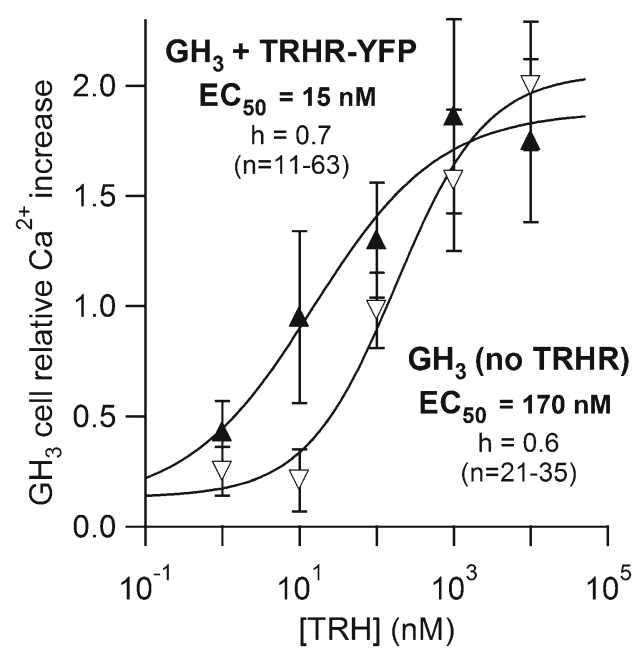

Fig. 7 Concentration dependence of TRH effects in HEK-H36/T1 cells and in $\mathrm{GH}_{3}$ cells with and without overexpressed TRH-Rs. a Dose-response curves for TRH-induced modulation of ERG currents in HEK-H36/T1 (open circles) and $\mathrm{GH}_{3}$ (closed circles) cells. Continuous lines correspond to Hill curves: $y=$ base $+(\max -$ base $) /[1$ $\left.+\left(\mathrm{EC}_{50} / x\right)^{h}\right]$ that best fitted the data. Values of the fitting parameters and number of cells tested at each hormone concentration are indicated in the graph. b Dose-response curves for the TRH-induced initial increase in $\left[\mathrm{Ca}^{2+}\right]_{i}$ levels. $\left[\mathrm{Ca}^{2+}\right]_{i}$ increases at the initial peak following TRH addition relative to the averaged $\mathrm{Ca}^{2+}$ level before adding TRH

PI3K-Akt signalling cascade by insulin via IGF-1 receptors has also been demonstrated [14].

\section{Differences in the hormone concentration dependence}

of the ERG channel modulation as a function of the cell type

As indicated before, it seems unlikely that the observed differences in the components involved in the hormonal regulation of ERG channels as a function of the cell type,
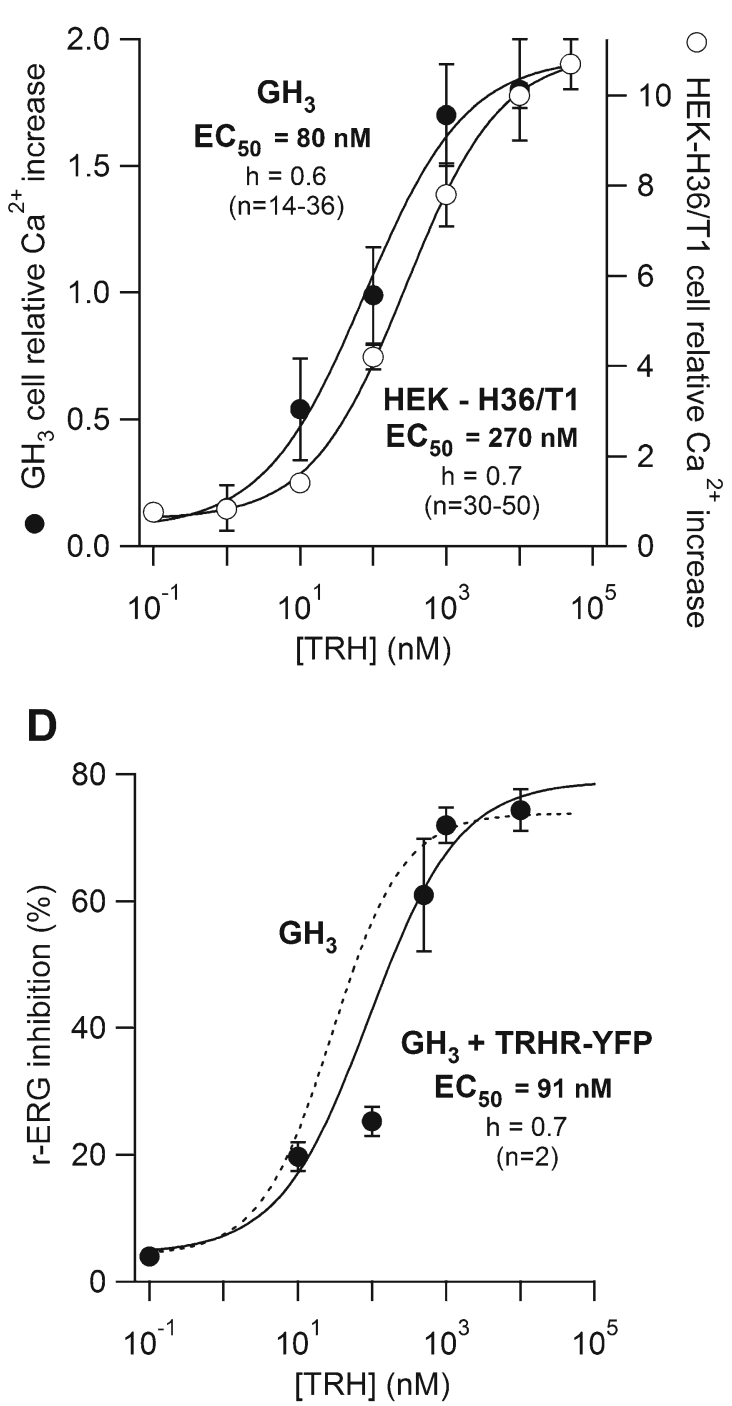

are shown. Data from HEK-H36/T1 and $\mathrm{GH}_{3}$ cells are depicted as in panel A. c Effect of TRH-R overexpression on TRH-induced $\left[\mathrm{Ca}^{2+}\right]_{i}$ increases in $\mathrm{GH}_{3}$ cells. Data values were obtained from cells in which the fluorescence of the labelled TRH-R was detected (TRHR-YFP) or not (no TRHR), respectively. d Concentration dependence of the TRH effect on rERG currents from $\mathrm{GH}_{3}$ cells overexpressing TRH-Rs. A dose-response curve corresponding to cells without exogenous TRHRs (dotted line) as in panel a, is also shown for comparison

occur at the level of the TRH-R itself, since they are specific for the ERG current modulation without altering the TRHinduced calcium responses. It is evident that only the exogenously expressed TRH-R1 subtype of TRH-R is present in the heterologous HEK-H36/T1 system. Furthermore, only a single class of TRH binding sites has been recognized in the $\mathrm{GH}_{3}$ pituitary cells that selectively express the TRH-R1 receptor [51]. Even though two alternatively spliced isoforms of TRH-R1 have been recognized in $\mathrm{GH}_{3}$ cells [21], 
they show almost identical affinities for TRH and display similar abilities to interact with $\mathrm{G}_{\mathrm{q}}$-like proteins, thus being able to activate the same signalling pathways $[20,22,36]$. To further explore the possible existence of differences in the coupling of the TRH-R to the signalling pathways, we compared the hormone concentration dependences for the $\mathrm{Ca}^{2+}$ and ERG responses in HEK-H36/T1 and $\mathrm{GH}_{3}$ cells. When the dose dependence of the rERG inhibition and the $\left[\mathrm{Ca}^{2+}\right]_{i}$ responses to TRH were examined in $\mathrm{GH}_{3}$ cells, similar sigmoidal shaped curves were observed yielding extrapolated $\mathrm{EC}_{50}$ values of around 30 and $80 \mathrm{nM}$, respectively (Fig. 7a, b), close to the Kd of TRH for its receptor and to the $\mathrm{EC}_{50}$ for stimulation of inositol phosphate generation, electrical activity, and secretory responses in GH cells $[2,19,46]$. The TRH concentration dependence of the $\left[\mathrm{Ca}^{2}\right.$ $\left.{ }^{+}\right]_{i}$ response remained quite similar in the HEK-H36/T1 cells $\left(\mathrm{EC}_{50}=270 \mathrm{nM}\right.$, Fig. 7b). Surprisingly, examination of the ability of the hormone to rightward shift the hERG I/V curves demonstrated a strong displacement of the $\mathrm{EC}_{50}$ for TRH to lower values of around $4 \mathrm{nM}$ (Fig. 7a). This displacement was accompanied by a narrowing of the doseresponse curve along the $x$ axis, increasing the cellular Hill equivalent from 0.7 to 2.7 , and yielding a maximum response at ca. $10 \mathrm{nM} \mathrm{TRH}$.

It is known that the presence of spare receptors (also referred to as receptor reserve), a phenomenon of some second messenger-coupled receptor cascades in which a fraction of the receptor population is sufficient to maximally activate the effector population, can provide a mechanism for obtaining a response at lower agonist concentrations also increasing the Hill coefficient $[17,39,46]$. The presence of a receptor reserve would be consistent with a TRH-R overexpression in the HEK-H36/T1 cells. However, receptor number does not appear to be the sole determinant of hormone dependence, since the dose-response displacement is not similarly observed for the HEK-H36/T1 cells calcium response. To check for the possibility that the intrinsic cell composition could also be involved in the different modulation of ERG currents parameters, we studied the hormone concentration dependence of the $\mathrm{Ca}^{2+}$ and ERG responses in $\mathrm{GH}_{3}$ cells in which the number of TRH-Rs was increased by transient transfection of fully functional TRH-Rs carrying a YFP fluorescent label at their carboxy terminus. The use of a labelled receptor not only allowed us to identify the successfully transfected cells, but also ensured that the individual fluorescent cells were indeed expressing a much larger amount of receptors than their non-fluorescent counterparts. As expected, the $\mathrm{GH}_{3}$ cells overexpressing the receptor exhibited $\left[\mathrm{Ca}^{2+}\right]_{i}$ responses showing some displacement toward lower hormone concentrations. However, unlike the modulation of the hERG kinetic parameters in HEK-H36/T1 cells, no significant differences in the Hill equivalent were caused by the increase in the cell receptor content (Fig. 7c). Finally, the strong shift in concentration dependence of the TRH-induced modulation of the HEKH36/T1 hERG currents was not manifested on the inhibition of the endogenous rERG currents of the fluorescent transfected $\mathrm{GH}_{3}$ cells (Fig. 7d). These data indicate that in addition to the increased number of receptors, some cellular factor(s) contribute differently to couple the receptor to the hERG channel modulation in the HEK-H36/T1 cells, further emphasizing the influence of the cell type in the molecular mechanism(s) involved in the TRH-evoked responses.

\section{Discussion}

The transduction pathway between TRH-R and the ERG K ${ }^{+}$ channels has been partially established by our group and others in cell types in which the two elements are natively or heterologously expressed [3, 4, 6, 8, 23, 40, 47, 48]. Binding of TRH to its receptor at the plasma membrane initiates a variety of intracellular signalling events with distinct physiological outcomes. While studying the roles of various $\mathrm{G}$ proteins and downstream cellular effectors in the context of ERG inhibition by TRH in $\mathrm{GH}_{3}$ and HEK-H36/T1 cells, we found several discrepancies between them, specifically regarding the coupling to $G$ proteins and the implication of $\beta \gamma$ dimers in the transduction of the signal [40]. To critically address this issue, we have studied the biomolecular processes beyond $\mathrm{G}$ protein coupling in these cell types. Signalling pathways are typically studied using different cell lines, and knowledge is compiled assuming that the cell line background is not important. However, different cell lines may not respond to a particular stimulus in the same way since they may not have the same basic cellular machinery and may show differences in their transduction pathway dynamics $[49,59]$. Our results here using $\mathrm{GH}_{3}$ and HEKH36/T1 cells show that the TRH pathway can implicate different downstream signalling elements in a celldependent way. We have also verified that those differences are not exclusively due to the overexpression of TRH-Rs in HEK-H36/T1 cells.

While Miranda et al. [40] described that regulation of ERG currents by TRH is coupled to $\mathrm{G}_{\mathrm{s}}$ in $\mathrm{GH}_{3}$ cells but not in HEK-H36/T1 cells, in this article we have analysed in depth the possible implication of $\beta \gamma$ dimers and Akt/PKB kinase in the transduction of the TRH signal to ERG. Thus we have studied the effects of several $\beta \gamma$ dimer scavengers such as $\beta$-ARK/CT [34] and phosducin [12], as well as the previously employed $G \alpha_{t}$ [40]. All three scavengers were able to significantly reduce the TRH-evoked rERG current inhibition in $\mathrm{GH}_{3}$ cells, demonstrating an evident implication of $\beta \gamma$ dimers as a necessary element of the signalling in these cells. Noticeably, the role of the dimers is specific for the modulation of the $\mathrm{GH}_{3}$ cell rERG currents, since the 
presence of the scavengers did not modify the $\mathrm{G}_{\mathrm{q} / 11^{-}}$and PLC-dependent intracellular $\mathrm{Ca}^{2+}$ rise also caused by TRH in these cells. In contrast to the behaviour observed in $\mathrm{GH}_{3}$ cells, none of the $\beta \gamma$ dimer scavengers was able to modify the hERG channels response to TRH in HEK-H36/T1 cells. Thus, whereas the transduction pathways activated by TRH in both cell types do share some common elements, they also implicate different ones converging on the same effector, i.e. the ERG channels. Since equivalent receptor and effectors are present in both cell types, such differences must rely on the cell-specific molecular compositions.

One of the proposed elements involved in the modulation of the endogenous pituitary cell ERG channels by TRH is a phosphorylation/dephosphorylation event $[4,23]$. Whereas the possible implication of some specific protein kinases (e. g. PKA and PKC) in this effect has been discarded [23, 47, 48], the identity of the phosphorylating enzyme and the molecular target of its action remains unknown. Nevertheless, phosphorylation by PKA [32, 53] and PKC [18] (but see [52]) of heterologously expressed hERG channels has been recognized as a modulatory mechanism. Although the basal activity of Akt/PKB has been previously reported to be necessary for the correct function of hERG in HEK293 cells [58], no data about its possible implication in the hormone-induced regulation of the channel is available to date. To study the involvement of this kinase in the TRH response, we have used an RNAi strategy, using siRNA mixes derived from human or rat Aktl sequences. These siRNA mixes strongly reduced (more than $80 \%$ ) the expression of not only Akt1, but also of Akt2 and Akt3 that show between $71 \%$ and $82 \%$ identity with the corresponding human and rat Akt1. More importantly, whereas knocking down Akt expression did not affect the TRH-induced rERG modulation in $\mathrm{GH}_{3}$ cells, it effectively impaired the HEKH36/T1 cell hERG kinetic modifications induced by the hormone. The effect of the siRNA mix was specific and not an off-target one, since it was mimicked by a specific siRNA for the human Akt1 mRNA. Pharmacological inhibition of Akt/PKB activation with wortmannin and depletion of the PI3K/Akt route following a quite long-term pretreatment with insulin (an effective activator of this route) further demonstrated that $\mathrm{Akt} / \mathrm{PKB}$ is indeed necessary for transduction of the signal from TRH-R to ERG channels in HEK-H36/T1 cells, but not in $\mathrm{GH}_{3}$ cells. Apart from being the first demonstration of Akt/PKB participation in an ERG channel response to a hormonal stimulus, these data again emphasize the importance of the cell type in such a signal transduction. The final indication that this is the case is provided by our data showing a different hormone concentration dependence for the TRH-induced effects on ERG in $\mathrm{GH}_{3}$ and HEK-H36/T1 cells.

Our findings raise the question as to what underlies the difference in TRH-R/G-protein/effector coupling seen between the two cell lines. At this moment, we cannot provide a definitive molecular explanation for the celldependent differences in this coupling. Since the same TRH-R is expressed in the $\mathrm{GH}_{3}$ and the HEK-H36/T1 cells, such differences should lie distal to the receptor itself. It also seems unlikely that the very few amino acid changes $(96 \%$ amino acid identity) between the rat and human ERG channel sequences [10] could explain the observed differences. Indeed, although it is plausible that some single amino acid alterations may affect the functional properties of the channels modifying their biophysical and/or regulatory characteristics, it has been demonstrated that hERG channels and their rat counterparts do not significantly differ in respect to their modulation by TRH when they are exogenously expressed in the same $\mathrm{GH}_{3}$ cells $[33,48]$. Also, the existence of a different set of auxiliary $\beta$ subunits in the two cell types cannot be disregarded [54]. As an alternative, the possibility of an interaction of the receptor with different $G$ proteins may explain the diverse mechanism(s) involved in ERG modulation. Whereas in many natural receptor systems the amount of $G$ protein available for interaction with receptors is not limiting, in some cases the availability of $\mathrm{G}$ protein becomes a limitation [31]. This phenomenon can be observed more often in recombinant systems, where the natural stoichiometry is altered by expressing receptors in surrogate cells, opening up the possibility that the high levels of receptor expression may tend to produce saturation of stimulus-response mechanisms and to recruit other cellular response elements [31]. As a consequence, either through activation of more than one $\alpha$-subunit of multiple $G$ proteins or through a significant increase in $\beta \gamma$-subunits, the increased receptor expression level may change the observed response. Note, however, that although receptor overexpression has been shown to induce some promiscuous coupling to $\mathrm{G}$ proteins $[15,28,38]$, this cannot fully explain the differences observed here, since some of them still remain after overexpressing the TRH-R in the $\mathrm{GH}_{3}$ cells. This would also tend to disprove the hypothesis that an increased number of receptors leads to a higher dimerization/oligomerization level, a phenomenon previously detected with the TRH-R $[25,45,50]$ that in some receptors has been shown to allow for a differential coupling to the transduction cascades [37, 44].

Another possibility to explain the observed differences is that the receptor/G-protein interaction is partially dependent upon the complement of downstream effectors present in each cell type. Thus, it has been shown that the efficiency of D3 dopamine receptor coupling to $\alpha-G_{0}$ is much greater in SH-SY5Y compared to HEK293 cells, despite a similar abundance of $\alpha-G_{0}$ in both cell types [57]. This led to the proposal that it is the endogenous level of the appropriate downstream effector(s) which determines the efficiency of specific receptor/G-protein interactions. It remains to be 
established whether a similar mechanism is involved in the differences in the TRH-induced pathways.

In summary, the results presented here show that, besides using common elements for signal transduction such as the $\mathrm{G}_{\mathrm{q} / 11}$-PLC route, TRH action also causes a cell-dependent regulation of the ERG channels through some different elements, since it implicates $\beta \gamma$ dimers but not Akt/PKB in $\mathrm{GH}_{3}$ cells, whereas in HEK-H36/T1 cells it implicates Akt/PKB but not $\beta \gamma$ dimers. Noticeably, $\beta \gamma$ dimers liberated by GPCRs from $\mathrm{G}_{\mathrm{i}}$ proteins reportedly bind to and activate PI3K $\gamma[26,29]$. However, TRH-R coupling to $G_{i}$ is not apparently involved in the modulation of rERG channels of the $\mathrm{GH}_{3}$ cells, since the effect of TRH on rERG is not impaired by pertussis toxin $[9,40]$, and because the effect remains intact when the hormone is added to cells in which the continuous presence of saturating levels of an agonist (e. g. somatostatin and oxotremorine $\mathrm{M}$ ) maintains activated classic inward rectifier $\mathrm{K}+$ channels via $\mathrm{G}_{\mathrm{i}}$ (Barros F. and Miranda P., unpublished results). This could explain the inability of the hormone to modulate the $\mathrm{GH}_{3} \mathrm{rERG}$ current via $\mathrm{Akt} / \mathrm{PKB}$. It would also be consistent with our proposal that a specific set of $\beta \gamma$ subunits released from a $\mathrm{G}_{\mathrm{s}}$ or $\mathrm{G}_{13}$ transducer is responsible for the TRH-induced ERG regulation in the $\mathrm{GH}_{3}$, but not in the HEK-H36/T1 cells [40]. Further work would be necessary to identify other molecular components of the signalling cascade leading to the Akt/ PKB-dependent modulation of hERG in this heterologous cell expression system.

Acknowledgements We thank Teresa González for the technical assistance and Dr. Kevin Dalton for proof reading the text. We also thank Dr. Angel Martínez-Nistal, head of the Scientific and Technical Services of the University of Oviedo, for the loan of the epifluorescence light source for our patch-clamp setup. This work was supported in part by Spanish Ministerio de Ciencia e Innovación (MICINN) Grant BFU2009-11262 and Spanish Ion Channel Initiative (SICI) Consolider-Ingenio Project CSD2008-00005. L.C. and J. F-T were supported by predoctoral fellowships from the Ministerio de Educación y Ciencia (MEC) and the Fondo de Investigación Científica y Técnica (FICYT) of Spain. A.M. holds a postdoctoral contract from SICIConsolider 2008.

\section{References}

1. Alonso-Ron C, Barros F, Manso DG, Gómez-Varela D, Miranda P, Carretero L, Domínguez P, de la Peña P (2009) Participation of HERG channel cytoplasmic structures on regulation by the $G$ protein-coupled TRH receptor. Pflügers Arch 457:1237-1252

2. Barros F, Delgado LM, Maciá C, de la Peña P (1991) Effects of hypothalamic peptides on electrical activity and membrane currents of "patch perforated" clamped $\mathrm{GH}_{3}$ anterior pituitary cells. FEBS Lett 279:33-37

3. Barros F, Delgado LM, del Camino D, de la Peña P (1992) Characteristics and modulation by thyrotropin-releasing hormone of an inwardly rectifying $\mathrm{K}^{+}$current in patch-perforated $\mathrm{GH}_{3}$ anterior pituitary cells. Pflügers Arch 422:31-39
4. Barros F, Mieskes G, del Camino D, de la Peña P (1993) Protein phosphatase $2 \mathrm{~A}$ reverses inhibition of inward rectifying $\mathrm{K}^{+}$currents by thyrotropin-releasing hormone in $\mathrm{GH}_{3}$ pituitary cells. FEBS Lett 336:433-439

5. Barros F, Villalobos C, García-Sancho J, del Camino D, de la Peña $\mathrm{P}$ (1994) The role of the inwardly rectifying $\mathrm{K}^{+}$current in resting potential and thyrotropin-releasing hormone-induced changes in cell excitability of $\mathrm{GH}_{3}$ rat anterior pituitary cells. Pflügers Arch 426:221-230

6. Barros F, del Camino D, Pardo LA, Palomero T, Giráldez T, de la Peña P (1997) Demonstration of an inwardly rectifying $\mathrm{K}^{+}$current component modulated by thyrotropin-releasing hormone and caffeine in $\mathrm{GH}_{3}$ rat anterior pituitary cells. Pflügers Arch 435:119-129

7. Barros F, Gomez-Varela D, Viloria CG, Palomero T, Giráldez T, de la Peña P (1998) Modulation of human erg K+ channel gating by activation of a $\mathrm{G}$ protein-coupled receptor and protein kinase $\mathrm{C}$. J Physiol 511:333-346

8. Bauer CK, Meyerhof W, Schwarz JR (1990) An inward-rectifying $\mathrm{K}^{+}$current in clonal rat pituitary cells and its modulation by thyrotropin-releasing hormone. J Physiol 429:169-189

9. Bauer CK, Davison I, Kubasov I, Schwarz JR, Mason WT (1994) Different $G$ proteins are involved in the biphasic response of clonal rat pituitary cells to thyrotropin-releasing hormone. Pflügers Arch 428:17-25

10. Bauer CK, Engeland B, Wulfsen I, Ludwig J, Pongs O, Schwarz JR (1998) RERG is a molecular correlate of the inward-rectifying $\mathrm{K}$ current in clonal rat pituitary cells. Recept Channels 6:19-29

11. Beitner-Johnson D, LeRoith D (1995) Insulin-like growth factor-I stimulates tyrosine phosphorylation of endogenous c-Crk. J Biol Chem 270:5187-5190

12. Blüml K, Schnepp W, Schröder S, Beyermann M, Macias M, Oschkinat H, Lohse MJ (1997) A small region in phosducin inhibits G-protein betagamma-subunit function. EMBO J 16:4908-4915

13. Brazil DP, Hemmings BA (2001) Ten years of protein kinase B signalling: a hard Akt to follow. Trends Biochem Sci 26:657-664

14. Castillo AI, Tolon RM, Aranda A (1998) Insulin-like growth factor-1 stimulates rat prolactin gene expression by a Ras, ETS and phosphatidylinositol 3-kinase dependent mechanism. Oncogene 16:1981-1991

15. Chabre O, Conklin BR, Brandon S, Bourne HR, Limbird LE (1994) Coupling of the $\alpha_{2 \mathrm{~A}}$-adrenergic receptor to multiple Gproteins. A simple approach for estimating receptor-G-protein coupling efficiency in a transient expression system. J Biol Chem 267:5730-5734

16. Chiang C-E, Roden DM (2000) The long QT syndromes: genetic basis and clinical implications. J Am Coll Cardiol 36:1-12

17. Cleland TA, Linster C (1999) Concentration tuning mediated by spare receptor capacity in olfactory sensory neurons: a theoretical study. Neural Comput 11:1673-1690

18. Cockerill SL, Tobin AB, Torrecilla I, Willars GB, Standen NB, Mitcheson JS (2007) Modulation of hERG potassium currents in HEK-293 cells by protein kinase C. Evidence for direct phosphorylation of pore forming subunits. J Physiol 581:479-493

19. de la Peña P, Delgado LM, del Camino D, Barros F (1992) Cloning and expression of the thyrotropin-releasing hormone receptor from $\mathrm{GH}_{3}$ rat anterior pituitary cells. Biochem J 284:891-899

20. de la Peña P, Delgado LM, del Camino D, Barros F (1992) Two isoforms of the thyrotropin-releasing hormone receptor generated by alternative splicing have indistinguishable functional properties. J Biol Chem 267:25703-25708

21. Franke TF (2008) PI3K/Akt: getting it right matters. Oncogene 27:6473-6488

22. Gershengorn MC, Osman R (1996) Molecular and cellular biology of thyrotropin-releasing hormone receptors. Physiol Rev 76:175191 
23. Gómez-Varela D, Giráldez T, de la Peña P, Dupuy SG, GarcíaManso D, Barros F (2003) Protein kinase C is necessary for recovery from the thyrotropin-releasing hormone-induced rERG current reduction in $\mathrm{GH}_{3}$ rat anterior pituitary cells. J Physiol 547:913-929

24. Hanada M, Feng J, Hemmings BA (2004) Structure, regulation and function of $\mathrm{PKB} / \mathrm{AKT}$ - a major therapeutic target. Biochim Biophys Acta 1697:3-16

25. Hanyaloglu AC, Seeber RM, Kohout TA, Lefkowitz RJ, Eidne KA (2002) Homo- and hetero-oligomerization of thyrotropin-releasing hormone (TRH) receptor subtypes. Differential regulation of betaarrestins 1 and 2. J Biol Chem 277:50422-50430

26. Hawkins PT, Anderson KE, Davidson K, Stephens LR (2006) Signalling through Class I PI3Ks in mammalian cells. Biochem Soc Trans 34:647-662

27. Hayakawa J, Ohmichi M, Tasaka K, Kanda Y, Adachi K, Nishio Y, Hisamoto K, Mabuchi S, Hinuma S, Murata Y (2002) Regulation of the PRL promoter by Akt through cAMP response element binding protein. Endocrinology 143:13-22

28. Hermans E (2003) Biochemical and parmacological control of the multiplicity of coupling at G-protein-coupled receptors. Pharmacol Ther 99:25-44

29. Hirsch E, Costa C, Ciraolo E (2007) Phosphoinositide 3-kinases as a common platform for multi-hormone signalling. J Endocrinol 194:243-256

30. Keating MT, Sanguinetti MC (2001) Molecular and cellular mechanisms of cardiac arrhythmias. Cell 104:569-580

31. Kenakin T (1997) Differences between natural and recombinant $G$ protein-coupled receptor systems with varying receptor/G protein stoichiometry. Trends Pharmacol Sci 18:456-464

32. Kiehn J (2000) Regulation of the cardiac repolarizing HERG potassium channel by protein kinase A. Trends Cardiovasc Med 10:205-209

33. Kirchberger NM, Wulfsen I, Schwarz JR, Bauer CK (2006) Effects of TRH on heteromeric rat erg $1 \mathrm{a} / 1 \mathrm{~b} \mathrm{~K} \mathrm{~K}^{+}$channels are dominated by the rerg1b subunit. J Physiol 571:27-42

34. Koch WJ, Hawes BE, Inglese J, Luttrell LM, Lefkowitz RJ (1994) Cellular expression of the carboxyl terminus of a $G$ proteincoupled receptor kinase attenuates $G$ beta gamma-mediated signalling. J Biol Chem 269:6193-6197

35. Lavan BE, Fantin VR, Chang ET, Lane WS, Keller SR, Lienhard GE (1997) A novel 160-kDa phosphotyrosine protein in insulin-treated embryonic kidney cells is a new member of the insulin receptor substrate family. J Biol Chem 272:21403-21407

36. Lee TW, Anderson LA, Eidne KA, Milligan G (1995) Comparison of the signalling properties of the long and short isoforms of the rat thyrotropin-releasing-hormone receptor following expression in Rat-1 fibroblasts. Biochem J 310:291-298

37. Lohse MJ (2010) Dimerization in GPCR mobility and signalling. Curr Opin Pharmacol 10:53-58

38. MacNulty EE, McClue SJ, Carr IC, Jess T, Wakelam MJO, Milligan $\mathrm{G}(1992) \alpha_{2}-\mathrm{C} 10$ adrenergic receptors expressed in Rat 1 fibroblasts car regulate both adenylylcyclase and phospholipase D-mediated hydrolysis of phosphatidylcholine by interacting with pertussis toxin-sensitive guanine nucleotide-binding proteins. J Biol Chem 267:2149-2156

39. Matthews JC (1993) Fundamentals of receptor, enzyme and transport kinetics. CRC, FL, USA

40. Miranda P, Giráldez T, de la Peña P, Manso DG, Alonso-Ron C, Gómez-Varela D, Domínguez P, Barros F (2005) Specificity of TRH-R coupling to G-proteins for regulation of ERG $\mathrm{K}^{+}$channels in $\mathrm{GH}_{3}$ rat anterior pituitary cells. J Physiol 566:717-736

41. Miranda P, Manso DG, Barros F, Carretero L, Hughes TE, AlonsoRon C, Domínguez P, de la Peña P (2008) FRET with multiply labeled HERG $\mathrm{K}^{+}$channels as a reporter of the in vivo coarse architecture of the cytoplasmic domains. Biochim Biophys Acta 1783:1681-1699

42. Nakanishi S, Catt KJ, Balla T (1995) A wortmannin-sensitive phosphatidylinositol 4-kinase that regulates hormone-sensitive pools of inositolphospholipids. Proc Natl Acad Sci USA 92:5317-5321

43. Palomero T, Barros F, del Camino D, Viloria CG, de la Peña $P$ (1998) A G protein $\beta \gamma$ dimer-mediated pathway contributes to mitogen-activated protein kinase activation by thyrotropinreleasing hormone receptors in transfected COS-7 cells. Mol Pharmacol 53:613-622

44. Park PS, Palczewski K (2005) Diversifying the repertoire of G protein-coupled receptors through oligomerization. Proc Natl Acad Sci USA 102:8793-8794

45. Pfleger KD, Kroeger KM, Eidne KA (2004) Receptors for hypothalamic releasing hormones TRH and GnRH: oligomerization and interactions with intracellular proteins. Semin Cell Dev Biol $15: 269-280$

46. Ramsdell JS, Tashjian AH Jr (1986) Thyrotropin-releasing hormone (TRH) elevation of inositol trisphosphate and cytosolic free calcium is dependent on receptor number. Evidence for multiple rapid interactions between TRH and its receptor. J Biol Chem 261:5301-5306

47. Schäfer R, Wulfsen I, Behrens S, Weinsberg F, Bauer CK, Schwarz JR (1999) The erg-like current in rat lactotrophs. J Physiol 518:401-416

48. Schledermann W, Wulfsen I, Schwarz JR, Bauer CK (2001) Modulation of rat erg1, erg2, erg3 and HERG $\mathrm{K}^{+}$currents by thyrotropin-releasing hormone in anterior pituitary cells via the native signal cascade. J Physiol 532:143-163

49. Selkirk JV, Price GW, Nahorski SR, Challiss RA (2001) Cell typespecific differences in the coupling of recombinant mGlulalpha receptors to endogenous $G$ protein sub-populations. Neuropharmacology 40:645-656

50. Song GJ, Jones BW, Hinkle PM (2007) Dimerization of the thyrotropin-releasing hormone receptor potentiates hormonedependent receptor phosphorylation. Proc Natl Acad Sci USA 104:18303-18308

51. Sun Y, Lu X, Gershengorn MC (2003) Thyrotropin-releasing hormone receptors - similarities and differences. J Mol Endocrinol 30:87-97

52. Thomas D, Zhang W, Wu K, Wimmer A-B, Gut B, Wendt-Nordahl G, Kathöfer S, Kreye VAW, Katus HA, Schoels KJ, Karle CA (2003) Regulation of HERG potassium channel activation by protein kinase $\mathrm{C}$ independent of direct phosphorylation of the channel protein. Cardiovasc Res 59:14-26

53. Thomas D, Kiehn J, Katus HA, Karle CA (2004) Adrenergic regulation of the rapid component of the cardiac delayed rectifier potassium current, IKr, and the underlying hERG ion channel. Basic Res Cardiol 99:279-287

54. Vacher H, Trimmer JS (2011) Diverse roles for auxiliary subunits in phosphorylation-dependent regulation of mammalian brain voltage-gated potassium channels. Pflugers Arch 462:631-643

55. Wanke E, Restano-Cassulini R (2006) Toxins interacting with ether-a-go-go-related gene voltage-dependent potassium channels. Toxicon 49:239-248

56. Weinsberg F, Bauer CK, Schwarz JR (1997) The class III antiarrhythmic agent E-4031 selectively blocks the inactivating inwardrectifying potassium current in rat anterior pituitary tumor cells $\left(\mathrm{GH}_{3} / \mathrm{B} 6\right.$ cells). Pflügers Arch 434:1-10

57. Zaworski PG, Alberts GL, Pregenzer JF, Im WB, Slightom JL, Gill GS (1999) Efficient functional coupling of the human D3 dopamine receptor to G(o) subtype of G proteins in SH-SY5Y cells. Br J Pharmacol 128:1181-1188 
58. Zhang Y, Wang H, Wang J, Han H, Nattel S, Wang Z (2003) Normal function of HERG $\mathrm{K}^{+}$channels expressed in HEK293 cells requires basal protein kinase $\mathrm{B}$ activity. FEBS Lett 534:125-132

59. Zhang Y, Opresko L, Shankaran H, Chrisler WB, Wiley HS, Resat H (2009) HER/ErbB receptor interactions and signalling patterns in human mammary epithelial cells. BMC Cell Biol 10:78-92

60. Zhou Z, Gong Q, Ye B, Fan Z, Makielski JC, Robertson GA, January CT (1998) Properties of HERG channels stably expressed in HEK 293 cells studied at physiological temperature. Biophys J $74: 230-241$ 